\title{
IN VITRO FERTILIZATION AND THE RIGHT TO PROCREATE: THE RIGHT TO NO
}

\author{
WILIIAM A. SIECK ${ }^{\dagger}$
}

\section{INTRODUCTION}

Unable to conceive by sexual intercourse, a woman and her husband are now pregnant with their second child. How? Her eggs were fertilized by his sperm in vitro-in a laboratory. Some of these fertilized eggs were implanted into her uterus, while others were frozen to make future attempts possible. The couple's success with in vitro fertilization ("IVF") gives them an opportunity to be parents, but leaves them with a difficult decision. They still have seven more frozen embryos. He is happy with only two children, while she wants to try to use the frozen embryos because they are made from the couple's eggs and sperm. Despite their differences, the couple is not worried about resolving the matter because they "trust each other." For other couples, however, trust has been insufficient when spread thinly over broken dreams. ${ }^{1}$ These couples, too, were unable to conceive through intercourse. The enormous expenditures of time, energy, and money required by the IVF process, however, were unavailing. When these unsuccessful couples have divorced, disputes over the disposition of the frozen embryos have not been easy to resolve. ${ }^{2}$ For example, one person sought custody, claiming one last, best chance to become a parent. The other person objected strenuously, fearing both the financial burden of mandatory child support payments and the emotional burden of separation from children whose existence was imagined only within marriage. ${ }^{3}$

${ }^{\dagger}$ B.A., 1991, University of Chicago; J.D. Candidate, 1999, University of Pennsylvania. With love for Jieney Kim Sieck and in memory of Kirin James Sieck and Hugo Evan Sieck, I offer some thoughts on marriage and children. My love and gratitude also go to my parents, my sister, and my brothers for making family more than a historical construct. Finally, and without attributing agreement, the critical comments of Professors Barbara Bennett Woodhouse and Seth Kreimer, and the tireless work of my fellow Law Review members have made this Comment better than I alone ever could. Errors are mine.

1 This description is based on the experiences of two couples, set forth fully infra Part III.

2 "Success" precludes neither divorce nor dispute. See supra note 1 and accompanying text. This textual paragraph should not be read as an assertion to that effect. Rather, it is based on empirical disputes and does not deny equally tragic possibilities.

${ }^{3}$ See infra Part III (describing actual IVF custody battles). While both cases discussed in Part III involved women seeking custody over the objection of a man, the roles could be re- 
Two state high courts have decided such disputes, each reaching a similar result. ${ }^{4}$ Although the courts applied different analytical approaches, ${ }^{5}$ both articulated a preference for a contract framework to resolve the competing claims of the divorcing spouses. ${ }^{6}$

This Comment argues that contract analysis, as between prospective parent-donors, is inadequate and inappropriate for resolving disputes over frozen embryos. Further, the interests of the parties ought not be balanced. Rather, the right to veto implantation should inhere in each party. Thus, in the absence of contemporaneous, mutual consent, the embryos of a married couple must not be implanted and those of an unmarried or divorced couple must either be discarded or donated for research.

Part I provides background information regarding the need for and nature of IVF. In Part II, the legal issues implicated by dispositional disputes are elucidated and explained. Part III details the facts and frameworks of the Davis and Kass decisions. Part IV analyzes and rejects the preference for contract frameworks. Part V then considers the rights and policies involved in IVF disposition disputes. This Comment advocates a bright-line

versed. In fact, a New Jersey case presents just such an alignment. See Genaro C. Armas, Court Says Divorced Woman Can't Use Her Five Fertilized Eggs, CHI. SUN-TimES, May 8, 1998, at 4, available in 1998 WL 5579719 (describing a sealed case where a man sought custody of frozen embryos while his ex-wife wanted them destroyed).

4 See Kass v. Kass, 696 N.E.2d 174, 175 \& n.1 (N.Y. 1998) (holding that when a couple divorced, unused preembryos-defined as "eggs which have been penetrated by sperm but have not yet joined genetic material"-were to be donated to a clinic for research as provided for in an agreement made prior to cryopreservation); Davis v. Davis, 842 S.W.2d 588, 604 (Tenn. 1992) (holding that an ex-husband's preference to let a clinic dispose of preembryos should prevail under the circumstances). Moreover, the results dictated by both courts accord with recommendations of other commentators. See, e.g., Elisa Kristine Poole, Allocation of Decision-Making Rights to Frozen Embryos, 4 AM. J. FAM. L. 67, 93 (1990) (advocating a default rule that embryos should not be implanted in the absence of an agreement between the donors); Jennifer Marigliano Dehmel, Comment, To Have or Not to Have: Whose Procreative Rights Prevail in Disputes over Dispositions of Frozen Embryos?, 27 CONN. L. REV. 1377,1402 (1995) (arguing that the right of the party not to procreate outweighs the right of the party seeking to reproduce because of the irreversibility of procreation and the psychological burden it places on an unwilling parent).

As will be explained, this Comment challenges the construction of the Constitution that equates the right to procreate with the right to avoid procreation. See infra Parts II, IV-V. Moreover, the doctrine of contract is rejected. See infra Part IV. This Comment does not dispute the results reached by the Kass and Davis courts, but rather, the means of reaching those results.

${ }^{5}$ Compare Kass, 696 N.E.2d at 180-81 (stressing that the prior agreement between the parties should be presumed to be valid and binding and that any ambiguities in the agreement should be analyzed using common law contract principles), with Davis, 842 S.W.2d at 603-04 (balancing the competing interests of the parties in the absence of an express statement of intent by the parties).

${ }^{6}$ See infra Part III (summarizing the holdings in Davis and Kass). 
approach which would permit either party to veto further attempts at IVF and would require that the embryos be discarded.

\section{THE WHAT AND WHY OF IN VITRO FERTILIZATION}

\section{Many couples are unable to have children ${ }^{7}$ for varied and complicated} reasons. $^{8}$ In 1978, however, Louise Brown, the first "test tube baby," was born, and the world learned that infertility could be countered. ${ }^{9}$ In the last twenty years, the development of alternative reproduction technologies

${ }^{7}$ See Institute for Science, Law, \& Tech. Working Group, ART into Science: Regulation of Fertility Techniques, 281 SCI. 651, 651 (1998) [hereinafter ISLAT Working Group] (estimating that "one of six American couples ... . are infertile"); John A. Robertson, Embryos, Families, and Procreative Liberty: The Legal Structure of the New Reproduction, 59 S. CAL. L. REV. 939, 945 (1986) (noting the increasing rate of infertility among certain population segments); Jennifer L. Carow, Note, Davis v. Davis: An Inconsistent Exception to an Otherwise Sound Rule Advancing Procreational Freedom and Reproductive Technology, 43 DEPAUL L. REV. 523,526 (1994) (noting that $15 \%$ of reproductively active couples "experience some difficulty having children").

The statistical increase in infertility rates has been challenged. See Virginia Rutter, Who Stole Fertility?, PsYCHOL. TODAY, Mar.-Apr. 1996, at 46, 47 (suggesting that fertility rates have not been falling, but rather that social and technological changes contribute to a heightened awareness and intolerance of "biology in the reproductive process").

The actual fertility rate is irrelevant to this Comment. More important is the increased reliance on fertility clinics. See George J. Annas, The Shadowlands-Secrets, Lies, and Assisted Reproduction, 339 NEW ENG. J. MED. 935, 935 (1998) (noting the growth of the infertility industry); Gina Maranto, Embryo Overpopulation, SCI. AM., Apr. 1996, at 16 (expecting the use of IVF clinics to continue to rise); Rutter, supra, at 48 (noting that the infertility industry is growing rapidly). Also critical is the consequent increase in frozen embryos subject to dispute. See Maranto, supra, at 16, 18 (expecting the number of frozen embryos to grow); Judy Peres, Giving Birth to Controversy, CHI. TRIB., July 21, 1998, at 1 (observing that approximately 100,000 frozen embryos are stored in the United States).

${ }^{8}$ See Owen K. Davis \& Zev Rosenwaks, In Vitro Fertilization, in 2 REPRODUCTIVE ENDOCRINOLOGY, SURGERY, AND TECHNOLOGY 2319, 2320-22 (Eli Y. Adashi et al. eds., 1996) (describing tubal factor infertility (tubal and pelvic adhesive disease), endometriosis (ectopic occurrence of endometrial tissue), male factor infertility (low motility, low concentration, and decreased normal forms), idiopathic infertility (unexplained infertility), immunologic infertility, and in utero exposure to diethylstilbestrol (DES)); Tanya Feliciano, Note, Davis v. Davis: What About Future Disputes?, 26 CONN. L. REV. 305, 306-07 (1993) (explaining that sexual intercourse sometimes fails to result in pregnancy because sperm are incapable of fertilizing an egg, because there are an insufficient number of eggs, or because there are complications with a woman's fallopian tubes or uterus); Alise R. Panitch, Note, The Davis Dilemma: How to Prevent Battles Over Frozen Preembryos, 41 CASE W. RES. L. REV. 543,546 (1991) (attributing infertility, in part, to "changes in sexual behavior and the increasing age at which" women are attempting to conceive a child); Rutter, supra note 7, at 65 (noting that causes of infertility are approximately $40 \%$ female factors, $40 \%$ male factors, and $20 \%$ unexplained).

${ }^{9}$ See P.C. Steptoe \& R.G. Edwards, Birth After the Reimplantation of a Human Embryo, 2 LANCET 366, 366 (1978) (announcing the birth of a healthy infant). For a popular account of the event, see The First Test-Tube Baby, TIME, July 31, 1978, at 58, describing the birth of the first test-tube baby. 
("ARTs"), including IVF, has provided an opportunity for many couples to bear children who share the couple's genetic blueprints. ${ }^{10}$

IVF is a process whereby a woman's eggs are fertilized by a man's sperm with surgical medical assistance. ${ }^{11}$ Generally, the first stage of the process is a controlled ovarian hyperstimulation, designed to produce large quantities of eggs. ${ }^{12}$ There exists a positive correlation between the number

${ }^{10}$ See Davis \& Rosenwaks, supra note 8, at 2320 (discussing the prominence of technologies such as IVF in infertility treatment); see also P. R. Brinsden \& P. A. Rainsbury, Introduction to A TEXIBOOK OF IN VITRO FERTILIZATION AND ASSISTED REPRODUCTION 21, 21-26 (Peter R. Brinsden \& Paul A. Rainsbury eds., 1992) (offering a short historical summary of in vitro fertilization); ISLAT Working Group, supra note 7, at 651 (noting that "parents now seemingly have greater control over how they bring children into the world" due to the growth of IVF in the last 20 years).

${ }_{11}$ More precisely, in vitro fertilization is "an assisted reproductive technique wherein oocytes are retrieved from the ovaries and fertilized extracorporeally with subsequent embryo replacement." Davis \& Rosenwaks, supra note 8, at 2321. "Oocytes" is the precise term for the female gamete contribution, popularly known as eggs or ova. The term "ova," however, does not find its way into the scientific literature very often, and thus will not be used.

For purposes of this Comment, the term "in vitro fertilization" will be used to describe fertility treatment whereby a man's sperm and woman's oocytes are combined ex corporeal in a laboratory environment. IVF is actually a subset of the broader area of "assisted reproductive technologies." See Judith F. Daar, Regulating Reproductive Technologies: Panacea or Paper Tiger?, 34 Hous. L. REV. 609, 619-20 \& nn.41-47 (1997) (noting that "ART is comprised of numerous methods used to match female and male gametes and successfully implant the joined material in a woman's body" and listing acronyms for the "slightly varied" techniques); Davis \& Rosenwaks, supra note 8, at 2320 (alluding to other ARTs); Louis N. Weckstein et al., Gamete/Zygote Intrafallopian Tube Transfer, in 2 REPRODUCTIVE ENDOCRINOLOGY, SURGERY, AND TECHNOLOGY, supra note 8, at 2335, 2336-52 (describing gamete intrafallopian transfer as an alternative to IVF). The differences among the techniques generally are not relevant to this Comment. Rather, the critical factor for this Comment is the presence of cryopreserved embryos, the use of which becomes a source of irreconcilable differences for some couples. See infra notes 20-21 and accompanying text (explaining the cryopreservation process).

12 This is the process of "pharmacologic stimulation of the ovaries ... with the objective of multi-follicular recruitment and hence retrieval of multiple oocytes." See Ilan Calderon \& David Healy, Endocrinology of IVF, in HANDBOOK OF IN VITRO FERTILIZATION 1, 4-12 (Alan Trounson \& David K. Gardner eds., 1993) (discussing endocrine evaluation for suitability and stimulation protocols); Davis \& Rosenwaks, supra note 8, at 2321, 2324-27 (discussing controlled ovarian hyperstimulation techniques); Francois Olivennes \& René Frydman, Friendly IVF: The Way of the Future?, 13 HUM. REPROD. 1121, 1121 (1998) (suggesting that "ovarian stimulation protocols have increased the amount of drug injected" into the woman which "may not be good for women's health and may not be the optimal treatment"); Robertson, supra note 7, at 948 (explaining the use of hormonal stimulation to increase egg production); Machelle M. Seibel, A New Era in Reproductive Technology: In Vitro Fertilization, Gamete Intrafallopian Transfer, and Donated Gametes and Embryos, 318 NEW ENG. J. MED. 828, 829 (1988) (describing the use of fertility drugs to induce ovulation and increase egg production). It is not uncommon for 10 or more eggs to be extracted in one procedure. See John A. Robertson, Prior Agreements for Disposition of Frozen Embryos, 51 OHIO ST. L.J. 407, 407 (1990). 
of eggs produced and pregnancy rates. ${ }^{13}$ After the eggs have been produced, they are retrieved surgically in a procedure known as "aspiration." 14 The retrieved eggs are then inseminated, and those that are fertilized are incubated for one to three days before they are ready to be implanted in the woman. ${ }^{15}$ At the time of implantation, the fertilized eggs may be zygotes, preembryos, or embryos. ${ }^{16}$ The

${ }^{13}$ See Davis \& Rosenwaks, supra note 8, at 2324 (noting that "most ART programs routinely employ controlled ovarian hyperstimulation in an effort to maximize pregnancy rates"); Allan Templeton \& Joan K. Morris, Reducing the Risk of Multiple Births by Transfer of Two Embryos After In Vitro Fertilization, 339 NEW ENG. J. MED. 573, 573 (1998) (concluding that "the chances of a live birth are related to the number of eggs fertilized, presumably because of the greater selection of embryos for transfer"). Because each stage in the process (production, retrieval, fertilization, implantation, conception) is less than $100 \%$ effective, beginning with the greatest number of eggs possible allows for the best odds from stage to stage. Retrieving a larger number of eggs not only increases the likelihood of pregnancy but also reduces the risks to the woman of repeated aspiration surgery. See Robertson, supra note 7, at 948 (noting that "the chance of pregnancy is very small if only one fertilized egg is transferred to the uterus"); Seibel, supra note 12, at 829-30 (describing aspiration methods). In the absence of a means to preserve the fertilized eggs, the maximum number possible must be implanted before they expire in the laboratory. See Marcia Joy Wurmbrand, Note, Frozen Embryos: Moral, Social \& Legal Implications, 59 S. CAL. L. REV. 1079, 1083 (1986) (noting that some clinics, in order to avoid the problem of "spare" embryos, remove only the eggs they expect to implant into the woman's uterus).

${ }^{14}$ See Davis \& Rosenwaks, supra note 8, at 2328-29 (describing laparoscopic oocyte retrieval and ultrasound-guided oocyte retrieval); Jeremy Osborn, Oocyte Retrieval and Maturation, in HANDBOOK OF IN VITRO FERTILIZATION, supra note 12, at 17, 18-29 (describing procedures used for the "collection, identification, and assessment of human oocytes"). "Initially, laparoscopic follicular aspiration was the dominant method of oocyte recovery." Davis \& Rosenwaks, supra note 8, at 2328. Laparoscopic procedures require general anesthesia and insertion of a needle through the abdomen. See id. (describing laparoscopic oocyte retrieval as being "performed under general anesthesia" and involving the insertion of a needle); see also Davis v. Davis, 842 S.W.2d 588, 591-92 (Tenn. 1992) (describing a series of subcutaneous and intermuscular injections, aspiration with a needle inserted through the abdomen while the woman is anesthetized, and implantation within 48 to 72 hours). Techniques which are "more sophisticated and more directly oriented to the patients' needs" have been developed, see Osborn, supra, at 18, and although these techniques are still invasive, they are less so and have become the "method of choice." See Davis \& Rosenwaks, supra note 8, at 2328.

${ }^{15}$ See Davis \& Rosenwaks, supra note 8, at 2329-31 (explaining methods of insemination, whereby oocytes are exposed to sperm, and the transfer of fertilized oocytes, now called preembryos or embryos).

${ }^{16}$ See DORLAND's ILLUSTRATED MEDICAL DICTIONARY 1859 (28th ed. 1994) (defining "zygote" as the "cell after synapsis at the completion of fertilization until first cleavage"); id. at 542-43 (defining "embryos" as "derivatives of the fertilized ovum that eventually become the offspring, during their period of most rapid development, i.e., after the long axis appears until all major structures are represented"); Alan Trounson \& Jeremy Osborn, In Vitro Fertilization and Embryo Development, in HANDBOOK OF IN VITRO FERTILIATION, supra note 12, at 57, 58-80 (describing development and transfer options); Lucinda L. Veeck, Cryopreservation of Embryos/Eggs, in 2 REPRODUCTIVE ENDOCRNOLOGY, SURGERY, AND TECHNOLOGY, supra note 8, at 2353, 2355 (providing precise definitions of the terms "zygote," "preembryo," and "embryo"). The preembryo occupies an interim stage of cell development. 
differences are biologically significant, but do not alter the legal analysis. $^{17}$

There is another positive correlation between the number of embryos transferred or implanted and the rate of pregnancy. ${ }^{18}$ As greater numbers of embryos are implanted at one time, however, multiple pregnancies become more likely, which pose risks to a woman's health. ${ }^{19}$ The tension between increasing pregnancy rates and protecting a woman's health has been eased by the ability to cryopreserve embryos in excess of the number to be implanted. ${ }^{20}$ These

${ }^{17}$ This is because a state may not limit the fundamental, constitutional rights of a person in favor of an entity which is not constitutionally protected. See infra Part II (providing an overview of the relevant legal issues); see also Davis, 842 S.W.2d at 592-94 \& n.15 (reviewing scientific testimony and noting that the distinction between embryo and preembryo is not dispositive); Annas, supra note 7, at 937 (calling the term "pre-zygote" "meaningless" and the term "pre-embryo" "euphemistic" because, "the most meaningful distinction is between extracorporeal embryos (over which male and female gamete providers have equal say) and implanted embryos (over which the pregnant woman has the ultimate decision-making authority)").

The biological differences are developmental. The legal irrelevance is due to the lack of an independent, constitutional interest of the embryo and of a limit on the State's interest if the donors' fundamental rights are implicated. See infra Part II.B (discussing the constitutional rights of privacy as they relate to procreation and family).

18 See Davis \& Rosenwaks, supra note 8, at 2330 ("Pregnancy rates rise as the number of embryos replaced increases."). This connection is has been challenged. See Templeton \& Morris, supra note 13, at 576 (finding that transferring more embryos increases the risks of multiple births "without necessarily improving the overall success rates of in vitro fertilization"). This challenge does not affect this Comment. The number of unused embryos, and not the number used, is critical. Moreover, using fewer embryos per implantation may actually increase the number in storage, thus exacerbating the problem of unused, disputed embryos. See supra note 11.

19 See id. at 2330-31 ("Beyond three or four embryos, however, the risk of high-order multiple gestation can increase sharply ...."); Trounson \& Osborn, supra note 16, at 80 ("Under optimal conditions, the maximum number of oocytes or embryos transferred should be restricted to two or three ....").

One article in a medical text notes that "[a] better pregnancy rate has consistently been correlated to a greater number of transferred preembryos.... However, the incidence of multiple pregnancy increases.... The risk of obstetrical and perinatal complications is higher .... In addition, decreased obstetrical risk is of particular importance for certain [IVF] patients ...." Veeck, supra note 16, at 2364; see also Templeton \& Morris, supra note 13, at 573 (observing that "[t]he high rate of multiple births resulting from in vitro fertilization is a major health issue" with considerable "medical, social, and financial consequences").

20 "The cryopreservation of gametes and embryos involves an initial exposure to cryoprotectants, cooling to subzero temperatures, storage, thawing, and finally ... return[ing] to a physiologic environment which allows further development." Jillian M. Shaw et al., Cryopreservation of Oocytes and Embryos, in HANDBOOK OF IN VITRO FERTILIZATION, supra note 12 , at 213,214 . See generally Veeck, supra note 16, at 2354-64 (describing cryopreservation methods). 
embryos remain frozen, awaiting future use. ${ }^{21}$

The ability to produce, fertilize, and preserve a number of eggs in one aspiration makes the IVF process less physically demanding on a woman and more promising for a couple. When the donors disagree with each other about the disposition of their frozen embryos, however, serious legal questions arise. Before considering the leading appellate decisions concerning the disposition of fertilized eggs, Part II briefly describes the principal legal issues involved.

\section{LEGAL FRAMEWORK AND ISSUES INVOLVED}

IVF permits time to lapse between the fertilization of a woman's eggs and conception. ${ }^{22}$ This Comment focuses on disputes between once-married donors with respect to custody and disposition rights over frozen embryos. These particular cases involve three questions. First, what is the legal nature of a frozen embryo? Second, should a couple's prior agreement matter in deciding disputes once the couple is no longer married? Third, if a prior agreement is inappropriate, inadequate, or unavailable, how should courts decide disputes over disposition ? $^{23}$ Subpart A provides a simple overview

21 "Perhaps the most valuable prospect of a cryopreservation program is the ability to enhance a patient's opportunity for pregnancy from a single stimulation cycle. If implantation fails after fresh transfer [the first, non-cryopreserved implantation], a second (or third) less expensive and less stressful attempt can be undertaken ...." Veeck, supra note 16, at 2354. To some extent, time favors implantation. This is because fertility treatments make the uterine lining less receptive to implantation in the short-term in order to induce ovulation. See Robertson, supra note 7, at 949 (noting that cryopreservation has helped to increase patient success rates by allowing patients to postpone embryo transfer). Further, the ability to cryopreserve preembryos reduces the cost of overall IVF procedures for most couples: the cost of aspiration is nearly five times the cost of transfer to the uterus. See Dehmel, supra note 4, at 1382 \& n.36 (citing Judy Licht, Frozen in Time: Storing of Embryos Boosts the Chances of Pregnancy-And Raises Ethical Questions, WASH. POST, Nov. 26, 1991, at Z10, for the proposition that the cost of extraction and implantation of a single egg is $\$ 10,000$ and the cost of transferring thawed embryos is about \$2000).

It is not clear how long cryopreserved preembryos will remain viable. Most experts recommend no more than 10 years in storage. See Wurmbrand, supra note 13, at 1098 (citing the 10-year limit on storage recommended by the British Committee of Inquiry into Human Fertilisation and Embriology). Healthy babies have been born from preembryos frozen for eight years. See Leslie Berkman, Embryos, Eggs and Ethics, L.A. TMMS, Apr. 3, 1994, at B1.

22 "Fertilization" is "the act of rendering gametes ... capable of further development" by fusion of gamete material. DORLAND's ILLUSTRATED MEDICAL DICTIONARY, supra note 16, at 617. "Conception" occurs later and is marked by implantation "in the endometrium." Id. at 365. Consequently, it is possible to fertilize an egg in vitro, implant it in the uterus, and not conceive. See id. at 617 (defining "in vitro fertilization").

${ }^{23}$ Science may be close to solving the problem. In the last year, children were born from eggs which had been frozen separate from sperm and which were fertilized after thawing. See Jeffrey Kluger, Eggs on the Rocks, TIME, Oct. 27, 1997, at 105, 105 (noting the first U.S. births of children from eggs frozen before they were fertilized). 
of the legal nature of a frozen embryo. Subpart B then explores and interprets the relevant federal constitutional doctrine surrounding the rights of the family and the right to procreate.

\section{A. A Frozen Embryo: Person, Property, or Special Respect?}

Fertilization outside the body is a recent phenomenon which raises legal, moral, and ethical dilemmas. Central to these dilemmas is a disagreement as to what a frozen embryo is. The growing literature on this subject suggests that there are three essential beliefs about the ontological reality of frozen embryos: person, property, or something other.

First, some argue that the embryo is a person. ${ }^{24}$ This analysis assumes that a human being exists at fertilization. ${ }^{25}$ Statutes in at least two states ar-

The considerations outlined in this Comment, however, are far from moot. First, cryopreservation of unfertilized eggs is only in its infancy, and is not "ready to go mainstream." Id.; see also Maranto, supra note 7, at 18 (cautioning that "[e]gg freezing is still highly experimental ... and may never pass muster"). Second, hundreds of thousands of cryopreserved embryos remain in storage and await disposition. See id. at 16,18 (predicting that the number of cryopreserved embryos in the United States, now approximately 100,000 , will continue to grow); Peres, supra note 7, at 1 (concurring in the estimate of 100,000 cryopreserved embryos). Third, the narrow reading of the right to procreate advanced in this Comment, see infra Parts II.B and V, is relevant to the government's ability to adequately regulate the IVF industry. See Annas, supra note 7, at 937 ("The abortion model of private decision making has been used to resist the regulation of assisted reproduction. ..."); Concerns About Assisted Reproduction, 351 LANCET 1524, 1525 (1998) (suggesting that regulation should be focus of scientific and governmental inquiry); ISLAT Working Group, supra note 7, at 651 (arguing that "reproductive technology has been insulated from regulations that apply to other medical fields"). This Comment seeks to narrow the IVF discussion by reference to the Constitution and to narrow the constitutional interpretation by reference to the IVF context.

${ }^{24}$ See The Warnock Report on Human Fertilisation and Embryology, \$11.11, in MARY WARNOCK, A QUESTION OF LIFE: THE WARNOCK REPORT ON HUMAN FERTILISATION \& EMBRYOLOGY 61 (1985) [hereinafter Committee of Inquiry] (citing the position that "the human embryo is seen as having the same status as a child or an adult"); see also Text of Vatican's Doctrinal Statement on Human Reproduction, N.Y. TIMES, Mar. 11, 1987, at A14 (endorsing respect for human life at its origin and respect for the act of procreation); infra notes 122-129 and accompanying text (describing trial testimony as to the status of an embryo in an IVF disposition dispute).

${ }_{25}$ See John A. Robertson, In the Beginning: The Legal Status of Early Embryos, 76 VA. L. REV. 437, $444 \&$ nn.24-25 (1990) (arguing that a "fervent minority believes that fertilization marks the emergence of a new person ... that deserves the same rights accorded other persons"). Robertson suggests that some of the confusion of issues may be attributable to imprecise use of language. Further, he argues that there should be little debate over whether a preembryo is living (it is) and, rather, the focus should be on "whether [the embryo] merit[s] the moral protection afforded to clearly defined persons." Id. at $444 \mathrm{n} .24$; see also Elisa Kristine Poole, Allocation of Decision-Making Rights to Frozen Embryos, 4 AM. J. FAM. L. 67, 69 (1990) (citing a January 1980 Joint Statement by the Archbishops of the Catholic Church which declared that "at the time of conception there comes into existence a new life" (citation omitted)). 
ticulate this perspective. ${ }^{26}$ Such a definition of human life suffers from two sharp criticisms. First, it does not recognize the biological and developmental differences that characterize early life. ${ }^{27}$ Second, this view is in tension with clear statements of the Supreme Court that pre-viable ${ }^{28}$ embryos do not possess the rights of a "person" for purposes of the Federal Constitution. ${ }^{29}$ Consequently, according to the Supreme Court view, the embryo has no rights which would impair those of a "person" under the Constitution. ${ }^{30}$

${ }^{26}$ See LA. REV. STAT. ANN. § 9:126 (West 1991) ("An in vitro fertilized human ovum is a biological human being which is not the property of the physician ... or the facility which employs him or the donors of the sperm and ovum."). Although no other state has explicitly defined preembryos as persons, others have criminalized the acts that result in their destruction. See, e.g., 720 ILL. COMP. STAT. ANN. 5/9-1.2(3)(b) (West 1993) (criminalizing the killing of an unborn child, defined as "any individual of the human species from fertilization until birth").

27 See Robertson, supra note 25 , at $444 \& \mathrm{n} .25$ (noting the inability of the preembryo to "interact, be conscious, have experiences, or be sentient"). In fact, a number of ethical committees accept experiments with preembryos because of the biologic determination that preembryos have not yet developed the "primitive streak," which occurs around 14 days after fertilization and which differentiates a preembryo from an embryo. See Kenneth J. Ryan, Ethical and Legal Implications, in 2 REPRODUCTIVE ENDOCRINOLOGY, SURGERY, AND TECHNOLOGY, supra note 8, at 1941, 1945-46 (defining preembryo as the fertilized egg from conception to formation of the primitive streak); Ethics Comm. of the Am. Fertility Soc'y, Ethical Considerations of the New Reproductive Technologies, 46 FERTILITY \& STERIIITY 1, 29S-30S (Supp. I 1986) [hereinafter Ethical Considerations] (explaining that a preembryo is a "genetically unique" cell mass which is not yet "developmentally individual").

${ }^{28}$ In the context of abortion, the Supreme Court has announced a framework for rights relating to a woman's ability to terminate her pregnancy. See infra notes 43-50 (discussing the constitutional right to an abortion as a right to privacy). The Court has refused to recognize a compelling state interest in a fetus, sufficient to override an individual's liberty or property interests, until such time as the fetus is "viable," by which the Court means "the time at which there is a realistic possibility of maintaining and nourishing a life outside the womb." Planned Parenthood v. Casey, 505 U.S. 833, 870 (1992) (O'Connor, Kennedy, Souter, JJ., separate opinion); see also Roe v. Wade, 410 U.S. 113 (1973).

${ }^{29}$ See Roe, 410 U.S. at 157 ("[N]o case could be cited that holds that a fetus is a person within the meaning of the Fourteenth Amendment."). "[T] he use of the word [person] is such that it has application only postnatally." Id. This does not stand as an absolute barrier to state regulation. It is a fundamental notion of constitutional law that a state may act whenever necessary if it can demonstrate a means of action that is narrowly tailored to a compelling state interest. Under such circumstances, a state may act even at the expense of individual constitutional rights. See, e.g., Adarand Constructors, Inc. v. Pena, 515 U.S. 200, 205, 237 (1995) (remanding for reconsideration a case involving federal contracting preferences for "socially and economically disadvantaged individuals" for a determination of whether interests served were compelling and whether interests were served by a narrowly tailored means (citation omitted)). Moreover, where fundamental rights are not affected and no suspect class is involved, the State need only demonstrate that particular legislation is rationally related to a legitimate state interest. See Bowen v. Gilliard, 483 U.S. 587, 598-603 (1987) (explaining that where the fundamental rights of the family are not infringed, the standard of review is whether a rational basis for a law exists).

${ }^{30}$ For this reason, the biological distinctions between the developmental stages of early life are less relevant. Rather, the "most meaningful distinction is between extracorporeal em- 
The second ontological possibility is that the preembryo is property. ${ }^{31}$ A property analysis focuses on the rights and interests of ownership and control which inhere in certain interested parties, usually the donors. ${ }^{32}$ In 1984, the American Fertility Society issued a statement that "gametes and concepti [preembryos] are the property of the donors. The donors therefore have the right to decide at their sole discretion the disposition of these items ...."33 Several objections to a broad property analysis are in order. First, this view does not resolve disputes between the individuals who donated the gametes. Such a perspective may be inadequate where, for example, property of the marriage ordinarily would be divided evenly between the parties. ${ }^{34}$ Second, unlike commercial goods, a frozen embryo possesses potential for autonomous human life not subject to the property rights of alienation, use, or exclusion.

A third ontological approach advocates the view that embryos are entitled to special respect, permitting limited donor discretion over preembryo disposition. ${ }^{35}$ In 1986 , the American Fertility Society clarified its position on the status of preembryos and announced that "the preembryo deserves respect greater than that accorded to human tissue but not the respect accorded to actual persons." ${ }^{36}$ This "special respect" is derived from both the preembryo's "potential to become a person and... [from] its symbolic

bryos ... and implanted embryos." Annas, supra note 7, at 937 . The critical issues here are what rights are implicated before pregnancy and how they are to be weighed.

31 See, e.g., York v. Jones, 717 F. Supp. 421, 425 (E.D. Va. 1989) (using a property analysis to establish a bailor-bailee relationship which required the Jones Institute for Reproductive Medicine to transfer custody of the Yorks' frozen preembryos to the Yorks after they moved to California).

${ }^{32}$ Understood broadly, property can include "every species of valuable right and interest. More specifically, ownership; the unrestricted and exclusive right to a thing; the right to dispose of a thing in every legal way, to possess it, to use it, and to exclude every one else from interfering with it." BLACK's LAW DICTMONARY 1216 (6th ed. 1990).

${ }^{33}$ Carow, supra note 7, at 541 (quoting American Fertility Soc'y, Ethical Statement on In Vitro Fertilization, 41 FERTILITY \& STERIIITY 12, 12 (1984)).

${ }^{34}$ See, e.g., Davis v. Davis, 842 S.W.2d 588, 591 n.6 (Tenn. 1982) (noting that such a division would be the worst case scenario because some preembryos would be destroyed, contrary to one party's wish, while some would be implanted, contrary to the other party's wish).

35 See Robertson, supra note 7, at $972-73$ (noting that the preimplantation embryo does not deserve the respect accorded to "persons" and has legal cognizance only to the extent that an actual person's interest in the disposition of the embryo is at stake).

${ }^{36}$ Ethical Considerations, supra note 27, at 29S-30S; see also Protection of Human Subjects; HEW Support of Human In Vitro Fertilization and Embryo Transfer: Report of the Ethics Advisory Board, 44 Fed. Reg. 35,033, 35,056 (1979) ("[T]he human embryo is entitled to profound respect; but this respect does not necessarily encompass the full legal and moral rights attributed to persons."). 
meaning for many people."37 This view is certainly the favorite among commentators $^{38}$ and accords with both state court ${ }^{39}$ and Supreme Court precedent. $^{40}$

The special respect view seems to be the most persuasive. It recognizes the dynamic nature of the embryo and the effect that flux has on the interests of the donors, the clinic, and the State. ${ }^{41}$ This view attempts to balance both present and future, individual and social interests. ${ }^{42}$

As explained in Part V, the special respect perspective may be the best way to think of IVF and disposition disputes constitutionally. Although this perspective preserves a sphere of consensual decision-making, it limits the zone of privacy when it implicates the actual or potential rights of third parties. The constitutional consideration is necessary in part because of its relevance to privacy and procreation and in part because the Constitution provides an enduring threshold.

\section{B. Constitutional Rights to Privacy}

In 1973, the Supreme Court recognized a woman's right to terminate an unwanted pregnancy as an exercise of her right of privacy in matters of pro-

37 Davis v. Davis, 842 S.W.2d 588, 596 (Tenn. 1992) (quoting Ethics Comm. of the Am. Fertility Soc'y, Ethical Considerations of the New Reproductive Technologies, 53 FERTLITY \& STERIITY 35S (Supp. 2 1990)).

${ }^{38}$ See, e.g., Committee of Inquiry, supra note $24, \S 11.17$ (concluding that a human embryo does not have the same legal status as a living person, but recommending that it have a "special status"); Poole, supra note 25, at 70-71 (adopting the special respect perspective); Ryan, supra note 27, at 1946 ("Most ethical review committees have suggested that the fertilized egg, preembryo, embryo, and fetus should be respected because they are humanly derived and living.").

39 See Davis, 842 S.W.2d at 596 ("We conclude that preembryos are not, strictly speaking, either 'persons' or 'property,' but occupy an interim category that entitles them to special respect because of their potential for human life.").

40 See Planned Parenthood v. Casey, 505 U.S. 833, 871 (1992) (observing that the state has an interest "in the protection of potential life"); Roe v. Wade, 410 U.S. 113, 162 (1973) (noting the state's legitimate, if not compelling, interest in "the potentiality of human life").

${ }^{41}$ The essential difficulty confronting courts is what to call a cell mass which, unlike a spleen or liver, has the unique potential to develop into a fully sentient being and which, unlike one sperm or one egg, is derived from two sentient beings.

${ }^{42}$ This is not to suggest that the future and social impact of ownership is never considered. That would not be true. See, e.g., In re Estate of Mahoney, 220 A.2d 475, 477 (Vt. 1966) (erecting a constructive trust whereby the legal title to property passed to one who, acting as trustee, held it for the benefit of another); JESSE DUKEMINIER \& STANLEY M. JOHANSON, WILLS, TRUSTS, \& ESTATES 2 (5th ed. 1995) (noting that means of devising and passing property are created by law and "are in all respects regulated by them"). In the IVF context, however, the future question is not "who shall have it?" but rather "who shall it be?" 
creation. ${ }^{43}$ Five years later, Louise Brown was born, the first child fertilized ex utero. ${ }^{44}$ Thus, a right construed to limit reproduction was succeeded by a new means of reproduction. Ironically, the right to privacy, so central to the right to abortion, ${ }^{45}$ is now strongly implicated by the confluence of technological development and a powerful desire to bear children. ${ }^{46}$

Courts and commentators alike have evaluated IVF dispositional disputes between divorced spouses by asserting that there are equal rights to procreate and to avoid procreation. ${ }^{47}$ The impact of these rights on IVF disputes is also relevant to the ability to regulate the industry. ${ }^{48}$ The contours of the rights to privacy, procreation, abortion, and family are informative when making decisions about the allocation of costs in IVF disputes. Therefore, the relevant constitutional doctrines will be discussed briefly.

There is no explicit reference to rights of privacy in the Constitution. Yet, for more than a century, Supreme Court decisions have recognized such rights in various contexts. ${ }^{49}$

43 See Roe, 410 U.S. at 164-66 (summarizing the right to abortion and permissible regulatory considerations).

44 See supra note 9 and accompanying text (describing the first "test-tube" baby).

45 See Casey, 505 U.S. at 857 ("The Roe Court itself placed its holding in . ... the liberty relating to intimate relationships, the family, and decisions about whether or not to beget or bear a child."); Roe, 410 U.S. at 153 ("This right of privacy ... is broad enough to encompass a woman's decision whether or not to terminate her pregnancy.").

${ }^{46}$ See Linda D. Applegarth, Emotional Implications, in 2 REPRODUCTIVE ENDOCRINOLOGY, SURGERY, AND TECHNOLOGY, supra note 8, at 1953, 1954 (noting that fertility is central to our culture and that for many, "reproduction is a basic expectation of life"); id. at 1961 (suggesting that "infertility patients pursue treatment with a tenacity equal to that of cancer patients" (citations omitted)); Ann Lalos et al., Depression, Guilt and Isolation Among Infertile Women and Their Partners, 5 J. PSYCHOSOMATIC OBSTETRICS \& GYNAECOLOGY 197, 197-206 (1985) (describing the essential importance, especially for women, of the ability to conceive and give birth); Rutter, supra note 7, at 65-66 (explaining that infertility has devastating effects on individuals because of the fundamental social nature of reproduction); Patrick J. Taylor, When is Enough Enough?, 54 FERTILITY \& STERIITY 772,772 (1990) (describing couples' tireless efforts to conceive and unwillingness to abandon treatment); see also supra note 7 (describing the growth of the fertility industry).

47 See Davis v. Davis, 842 S.W.2d 588, 600-01 (Tenn. 1992) (evaluating the right to procreational autonomy as the right to procreate and the right not to procreate); Dehmel, supra note 4 , at 1402 (conceding that there are equal rights to procreate and not to procreate); Poole, supra note 4, at 93 (suggesting the equality of the right to procreate and the right to avoid procreation).

${ }^{48}$ See Annas, supra note 7, at 937 (stating that the abortion model of privacy has "been used to resist the regulation of assisted reproduction").

49 In 1973, Justice Blackmun stated for the Court:

The Constitution does not explicitly mention any right of privacy. In a line of decisions, however, going back perhaps as far as Union Pacific $R$. Co. v. Botsford, 141 U.S. 250, 251 (1891), the Court has recognized that a right of personal privacy, or a guarantee of certain areas or zones of privacy, does exist under the Constitution. In varying contexts, the Court or individual Justices have, indeed, found at least the 
These decisions make it clear that only personal rights that can be deemed "fundamental" or "implicit in the concept of ordered liberty" ... are included in this guarantee of personal privacy. They also make it clear that the right has some extension to activities relating to marriage,... procreation,... contraception,... family relationships, ... and child rearing and education.... 5

As the foregoing statement illustrates, much of the Court's discussion of the right to privacy has centered on the family. The rights of the family have a long pedigree with the Supreme Court. ${ }^{51}$ These rights have been defined in the context of formation, including consenting adults' right to marry, divorce, and procreate; and the context of function, including the rights to the control and companionship of children.

\section{Rights of Formation: Marriage, Divorce, and Procreation}

The importance of marriage has never escaped the Court's notice. Marriage has been treated as a "sacred obligation... [u]pon [which] society may be said to be built, and out of its fruits spring social relations and social obligations and duties, with which government is necessarily required to deal." 52 In addition, the right of marriage has been deemed so fundamental that the opportunity to divorce and remarry may not be barred for purposes of administrative efficiency. ${ }^{53}$ The Constitution thus protects both the for-

roots of that right in the First Amendment,... in the Fourth and Fifth Amendments, ... in the penumbras of the Bill of Rights, ... in the Ninth Amendment, ... or in the concept of liberty guaranteed by the first section of the Fourteenth Amendment....

Roe, 410 U.S. at 152 (citations omitted).

50 Id. at 152-53 (citations omitted).

51 See H.L. v. Matheson, 450 U.S. 398, 409 (1981) (upholding a requirement of parental notice when an immature, dependent minor seeks an abortion); Wisconsin v. Yoder, 406 U.S. 205, 213-14 (1972) (protecting parental control over children's religion and education); Skinner v. Oklahoma, 316 U.S. 535, 541 (1942) (describing marriage and procreation as "basic civil rights of men"); Meyer v. Nebraska, 262 U.S. 390, 399 (1923) (holding that constitutionally protected liberties include the right to "marry, establish a home and bring up children"); Reynolds v. United States, 98 U.S. 145, 165 (1878) (holding that although marriage is a "sacred obligation" it is also a "civil contract").

52 Reynolds, 98 U.S. at 165; see also Loving v. Virginia, 388 U.S. 1, 12 (1967) (holding an anti-miscegenation law violative of the Due Process Clause where the law deprived the plaintiffs of the right to marry, "one of the vital personal rights essential to the orderly pursuit of happiness by free men"); Griswold v. Connecticut, 381 U.S. 479, 486 (1965) (holding that a restriction of contraceptive use by married couples violated the Due Process Clause of the Fourteenth Amendment because it was "repulsive to the notions of privacy surrounding the marriage relationship[]. . . . a right of privacy older than the Bill of Rights").

${ }^{53}$ See Boddie v. Connecticut, 401 U.S. 371,383 (1971) (holding that it is an unconstitutional violation of the Due Process Clause of the Fourteenth Amendment to bar parties from 
mation and the dissolution of the marital relationship. Due to the fundamental nature of the right to marry, restrictions on the right are strictly scrutinized to determine whether they are "closely tailored to effectuate only [important state] interests." 54

Particularly relevant in the context of family formation is the right to procreate, announced in Skinner v. Oklahoma. ${ }^{55}$ Jack Skinner was prosecuted under an Oklahoma statute, providing that criminals convicted on two or more occasions for crimes involving "moral turpitude" would be rendered "sexually sterile." The statute exempted certain crimes from coverage, those which might now be characterized as "white collar" offenses. 57 The state began proceedings to sterilize Skinner because he had been convicted once for stealing chickens and convicted twice for armed robbery. ${ }^{58}$

After subjecting the statute to "strict scrutiny," 59 the Court found that the law violated the Equal Protection Clause of the Fourteenth Amendment. ${ }^{60}$ The Court explained the need for such scrutiny because the law infringed on the right to procreate, "one of the basic civil rights of man. Marriage and procreation are fundamental to the very existence and survival of the race." ${ }^{.61}$

The link made between "marriage and procreation" is noteworthy in an opinion that does not discuss Mr. Skinner's marital status and that does not address whether the right of procreation may be confined to the marriage relationship. ${ }^{62}$ Notably, the Court did not vest in any one person the right,

divorce proceedings for failure to pay court costs where the parties sought a divorce in good faith and were unable to pay court costs due to uncontested indigency).

54 See Zablocki v. Redhail, 434 U.S. 374, 388 (1978) (holding that a law barring marriage by those with delinquent child support obligations was an unconstitutional violation of the Equal Protection Clause of the Fourteenth Amendment).

55316 U.S. 535 (1942).

56 Id. at 536-37.

57 See id. at 537 (excluding "violation of the prohibitory laws, revenue acts, embezzlement, or political offenses" (citation omitted)).

${ }^{58}$ See id. The Act provided for notice, an opportunity to be heard, and trial by jury. See id. at 536. Because the Court declined to consider the procedural objection, the adequacy of the proceedings is presumed. See id. at 538 (declining to address Skinner's due process claim because his equal protection argument afforded an adequate remedy).

59 See id. ("[S]trict scrutiny of the classification which a state makes in a sterilization law is essential ....").

${ }^{60}$ See id. at $541-42$.

61 Id. at 541.

62 In a limited sense, the right of procreation has since been extended to unmarried couples-at least to the extent of a couple's right to try to prevent pregnancy and a woman's right not to endure pregnancy as a punishment for violating a prohibition on fornication. See infra notes 72-75 and accompanying text (explaining the rights of an unmarried couple to have access to contraception in order to prevent pregnancy). It is not clear, however, if the right has lost its moorings. Consider, for example, Quilloin v. Wolcott, 434 U.S. 246 (1978) and Mi- 
as against another, to procreate. ${ }^{63}$ The Court feared that the Act could "cause races or types which are inimical to the dominant group to wither and disappear [and] ... could readily become a rule of human genetics." ${ }^{964}$ In sum, the Court sought to protect the individual reproductive function against intrusion by the State, absent compelling circumstances. ${ }^{65}$

chael H. v. Gerald D., 491 U.S. 110 (1989), both favoring marriage over biology. The Court has not answered the question regarding whether unmarried individuals have a right to have children. The question is squarely presented in the context of IVF custody disputes between divorcing couples, where each party is effectively unmarried and does not yet have a child. Rather, the Court has been confronted with the question post hoc by unmarried parties who already have children. It is suggested in Part V that this is a distinction with a difference.

${ }^{63}$ See Ryan, supra note 27, at 1949 ("In Skinner v. Oklahoma ..., the court struck down mandatory sterilization of habitual criminals because it interfered with the right of procreation.").

Skinner, 316 U.S. at 541-42. According to one scholar, a small study of IVF claims in Britain (the "British study") suggests that there is a eugenic aspect to patient selection. See Deborah Lynn Steinberg, A Most Selective Practice: The Eugenic Logics of IVF, 20 WOMEN'S STUD. INT'L F. 33, 34 (1997) (suggesting that IVF practice emphasizes conventional and heterosexual notions of "fitness"). Steinberg purports to demonstrate "the ways in which IVF selection practices can be seen to relate in direct and indirect ways to the reproduction of "ableist, class oppressive, heterosexist, and racist social divisions." Id. at 34.

Of course, the British study is an indictment of the position taken by this Comment that the constitutional protection of reproductive acts, not ability, is limited by the marriage and family preferences in which the right is rooted. To that extent, this Comment and the British study may not agree. This Comment takes no position on the validity of same-sex marriages or of alternative family formations. Rather, this Comment, in essence, argues that the import to one individual of becoming a biological parent does not outweigh the State's interest in minimizing disputes and in limiting a right to those who have demonstrated a commitment to another.

More important, perhaps, is the British study's assertion of eugenic behaviors pervading a private, largely unregulated industry. If Skinner was concerned with the limited opportunities of disfavored social groups, then the private and unregulated selection by fertility clinics seems to do the same. The ability of the government to regulate such clinics, however, could be impaired by a broad assertion that the individual right of procreation is being infringed. Consequently, the question of whether a fundamental right is involved is of extreme importance to the ability of the government to regulate such clinical procedures. See supra notes 23, 49 (citing sources which explore the fundamental rights question with regard to regulation).

${ }^{65}$ It is difficult to imagine what those circumstances might be. For a much maligned indication, see Buck v. Bell, 274 U.S. 200, 207 (1927), upholding the sterilization of a mentally deficient woman in a state institution because "[t]hree generations of imbeciles are enough." See also In re Moe, 432 N.E.2d 712, 721-24 (Mass. 1982) (noting that it was important to protect an incompetent person's individual rights and holding that a court must look carefully at a specified set of factors before permitting an incompetent individual to be sterilized). Likely, Buck is no longer good law. See LESLIE J. HARRIS ET AL., FAMILY LAW 207 (1996) (noting that Skinner casts doubt on Buck). The trouble is not with the result, but rather with the deferential standard applied in Buck. Compare Buck, 274 U.S. at 207 (deferring to the legislature's determination of incompetence and noting that "we cannot say as a matter of law that the grounds do not exist" for sterilizing those who are incompetent and who are "mani- 
Although Skinner clarified the right to be free from state intrusion into the physical aspects of reproduction, it did not contemplate whether there was any protection of the right to avoid procreation. That question was raised when, bolstered by social change in the 1960 s, laws regulating contraception were contested because they operated "directly on an intimate relation of husband and wife."

In Griswold v. Connecticut, the Court enunciated a married couple's right to be free of arbitrary state restrictions on access to contraceptives for the purpose of preventing pregnancy. ${ }^{67}$ The Court in Griswold derived the right to contraception from the right to privacy in one's marital relations. ${ }^{68}$

Writing for the plurality in Griswold, Justice Douglas found a right to privacy in the penumbra of the Bill of Rights and found that this right to privacy encompassed consensual behavior in "the sacred precincts of marital bedrooms." J9 Justice Goldberg, writing for a three-Justice concurrence, agreed that the "the rights to marital privacy ... are of similar order and magnitude as the fundamental rights specifically protected,"70 but thought those rights to be derived from the Ninth Amendment reservation of rights to the people. ${ }^{71}$

In Eisenstadt v. Baird, ${ }^{72}$ the Court extended the right of contraception to unmarried individuals. ${ }^{73}$ Writing for a three-Justice plurality, Justice Brennan found that a law limiting access to contraceptives was violative of the

festly unfit for continuing their kinds"), with Skinner, 316 U.S. at 541 (requiring strict scrutiny of laws that infringe upon reproduction).

${ }^{66}$ Griswold v. Connecticut, 381 U.S. 479, 482 (1965).

67 See id. at 485-86 (" [A] 'governmental purpose to control or prevent activities constitutionally subject to state regulation may not be achieved by means which sweep unnecessarily broadly and thereby invade the areas of protected freedoms." (quoting NAACP v. Alabama, 377 U.S. 288, 307 (1964))). The standard of review applied by the Court was unclear. The plurality simply found the law "overbroad" with a "maximum destructive impact" on a protected liberty. Id. at 485 . The concurring opinion applied strict scrutiny to the law, finding that the law was not a necessary means to a compelling end. See id. at 497.

${ }^{68}$ See id. at $485-86$ (Douglas, J., plurality opinion) (noting that the marital relationship lies "within the zone of privacy created by several fundamental constitutional guarantees" and characterizing the right to privacy in marriage as "a right of privacy older than the Bill of Rights").

69 Id. at 485 .

${ }^{70}$ Id. at 495 (Goldberg, J., concurring).

71 See id. at 486-87 ("The right to marital privacy ... is supported both by numerous decisions of this Court... and by the language and history of the Ninth Amendment."); see also U.S. CONST. amend. IX ("The enumeration in the Constitution, of certain rights, shall not be construed to deny or disparage others retained by the people.").

72405 U.S. 438 (1972).

73 See id. at 442. 
Equal Protection Clause, even under a deferential rational relation test. ${ }^{74}$ Justice Brennan concluded that "[i]f the right of privacy means anything, it is the right of the individual, married or single, to be free from unwarranted governmental intrusion into matters so fundamentally affecting a person as the decision whether to bear or beget a child." ${ }^{, 75}$ The breadth of the pronouncement is striking. First, the right to bear a child was not presented in Eisenstadt; there the only question was access to contraception. Second, the individual right articulated in Eisenstadt is derived from the fundamental effect that a denial of such a right would have on a person. ${ }^{76}$ To the extent that a decision affects third parties, the state may have a greater interest in the limits on decision-making power. Grounding the language in the facts, it may be limited to matters which "fundamentally affect[] a person.","77 Whereas the decision to have children fundamentally affects at least three people (two parents and a fetus which becomes a child) and the state, the effects of the decision not to have children are more limited.

Despite the right of access to contraception, unwanted pregnancies still occurred after Eisenstadt. ${ }^{78}$ Women seeking to terminate their pregnancies, however, were confronted with state restrictions on access to abortions. ${ }^{79}$ In Roe v. Wade, the Court limited the states' ability to restrict access to abortion. $^{80}$ The Court first explored the history of abortion laws, finding the

74 See id. at 447 (explaining that no "ground of difference ... rationally explains the different treatment accorded married and unmarried persons under" the Massachusetts statute). Justice Brennan noted the possibility that the statute infringed on fundamental freedoms under Griswold, but did not reach the question "because the law fail[ed] to satisfy even the more lenient equal protection standard." Id. at 447 n.7; see also U.S. CONST. amend. XIV, § 1 ("IN]or shall any State ... deny to any person within its jurisdiction the equal protection of the laws.").

75405 U.S. at 453 (emphasis added).

$76 \mathrm{See}$ id. at 448-49 (noting that it is "unreasonable to assume that Massachusetts has prescribed pregnancy or the birth of an unwanted child as punishment for fornication, which is a misdemeanor").

77 Id. at 453 .

${ }^{78}$ See Planned Parenthood v. Casey, 505 U.S. 833, 853 (1992) ("[C]oncerns are present when the woman confronts the reality that, perhaps despite her attempts to avoid it, she has become pregnant."); LEON SPEROFF \& PHIIIP D. DARNEY, A CLINICAL GUIDE FOR CONTRACEPTION 2 (1992) (inferring from the high proportion of abortions among American women compared to abortion rates among women in other countries, the "unappreciated, but real, problem of unintended pregnancy" in the United States); Charles F. Westoff, Unintended Pregnancy in America and Abroad, 20 FAM. PLAN. PERSP. 254, 255 (1988) (estimating that about half of pregnancies in the United States are unplanned).

79 See Roe v. Wade, 410 U.S. 113, 129 (1973) ("[C]riminal abortion laws in effect in a majority of States today .... generally proscrib[e] abortion or its attempt at any time during pregnancy except when necessary to preserve the pregnant woman's life ....").

${ }^{80}$ See id. at 164-66 (holding that a first trimester abortion is left to the decision of a woman and her physician, a second semester abortion may be regulated to protect maternal 
prohibitory form these laws had assumed of "recent vintage" in this country. ${ }^{81}$ Next, the Court considered the interests of a prospective mother, ${ }^{82}$ a fetus, ${ }^{83}$ and the State. ${ }^{84}$ Finding that a fetus was not a "person" under the Federal Constitution ${ }^{85}$ and that the State could not have a compelling interest in a nonviable fetus, ${ }^{86}$ the Court held that the first three months of pregnancy would be controlled exclusively by the physician-patient relationship. ${ }^{87}$ During that first trimester, a woman's right to "bear or beget a child" is paramount, and she can terminate the pregnancy for any reason or no reason at all, so long as she can find a doctor willing to perform the procedure. ${ }^{88}$ The Court explained that the burdens of unwanted parenthood were

health, and a third trimester abortion may be prohibited except where necessary to protect the life or health of the woman).

81 See id. at 129-30, 130-47 (noting that current laws derived "from statutory changes effected, for the most part, in the latter half of the 19th century").

82 See id. at 152-56 (finding a right to privacy under the Fourteenth Amendment which "includes the abortion decision"). Recall that if the Eisenstadt dictum is given full force, this right to privacy includes the decision whether to "bear or beget a child." Eisenstadt v. Baird, 405 U.S. 438, 453 (1972).

${ }^{83}$ See Roe, 410 U.S. at $156-62$ (determining that a fetus was not a "person" entitled to constitutional protection and refusing to sanction any single view of when life begins). This is not to say that the State may not confer benefits on a fetus or give it a legal status. It is to say, however, that when tension exists between the legal rights of a person and a fetus, those of the person will prevail. Thus, the fetus is not a "person" under the Fourteenth Amendment; men and women are.

${ }^{84}$ See id. at 162-64 (determining that the state interest in maternal health becomes compelling at the conclusion of the first trimester because evidence demonstrates that the risk from abortion increases as the duration of the pregnancy lengthens, and determining that the state interest in the potential life of the fetus becomes compelling after viability when the fetus "presumably has the capability of meaningfil life outside the mother's womb").

${ }^{85}$ See id. at 158 ("[T] he word 'person,' as used in the Fourteenth Amendment, does not include the unborn.").

${ }^{86}$ See id. at 163 ("With respect to the state's important and legitimate interest in potential life, the 'compelling' point is at viability."). Viability is the point at which, with or without assistance, the fetus is capable of survival outside the mother. See id. at 160 (defining viability). After viability, a state may "regulate, and even proscribe, abortion except where it is necessary ... for the preservation of the life or health of the mother." Id. at 165.

${ }^{87}$ See id. ("For the stage prior to approximately the end of the first trimester, the abortion decision and its effectuation must be left to the medical judgment of the pregnant woman's attending physician."). The holding was premised upon the relative dangers presented to a woman during the first three months of pregnancy and the dangers of an abortion during those same three months. See id. at 150 ("Mortality rates for women undergoing early abortions, where the procedure is legal, appear to be as low or lower than the rates for normal childbirth.").

${ }^{88}$ Griswold and Eisenstadt could have stood for the proposition that couples have a right to avoid pregnancy. Such a reading would, however, create other concerns. As an initial matter, such an interpretation would imply punishment for wrongful acts: If one has sex, one must deal with the consequences. In Roe, the Court noted that "no court or commentator has taken the [deterrence] argument seriously." 410 U.S. at 148. Further, "“[i]t would be plainly unreasonable to assume that [the state] has prescribed pregnancy and the birth of an unwanted 
too great to be imposed where a parent exercised the decision not to assume that responsibility. ${ }^{89}$ In Roe, the challenge to the law was facial, not "as applied. $" 90$ The Court did not balance the interests of specific parties in the case. It did not suggest that the burdens on a particular woman and a particular man ought to be assessed and then evaluated. ${ }^{91}$ The Court could have recognized the competing rights to procreation and could have prohibited abortion where a particular man's interest in becoming a parent outweighed a particular woman's interest in not doing so. ${ }^{92}$ Finding the effects

child ... as punishment for fomication." Carey v. Population Servs. Int'l, 431 U.S. 678, 695 (1977) (Brennan, J., plurality opinion) (alteration in original) (quoting Eisenstadt v. Baird, 405 U.S. 438,448 (1972)).

Moreover, such a construction would create tension between a desire to punish and the right to contraception. See Planned Parenthood v. Casey, 505 U.S. 833, 859 (1992) (O'Connor, Kennedy, Souter, JJ., separate opinion) ("Roe's scope is confused by the fact of its concern with postconception potential life, a concern otherwise likely to be implicated only by some forms of contraception protected independently under Griswold . ...").

89 The Court has noted the burdens of unwanted pregnancy.

Specific and direct harm medically diagnosable even in early pregnancy may be involved. Maternity, or additional offspring, may force upon the woman a distressful life and future. Psychological harm may be imminent. Mental and physical health may be taxed by child care. There is also the distress, for all concerned, associated with the unwanted child, and there is the problem of bringing a child into a family already unable, psychologically and otherwise, to care for it. In other cases, as in this one, the additional difficulties and continuing stigma of unwed motherhood may be involved.

Roe, 410 U.S. at 153.

${ }^{90}$ See id. at 120 (noting that Jane Roe "instituted this federal action" seeking "a declaratory judgment that the Texas criminal abortion statutes were unconstitutional on their face").

91 See id. at 165 n.67 ("Neither in this opinion nor in [its companion] ... do we discuss the father's rights, if any exist in the constitutional context, in the abortion decision. No parental right has been asserted... [and we] need not now decide whether [spousal consent] provisions ... are constitutional."). The Court did address the constitutionality of a spousal consent requirement in Planned Parenthood v. Danforth, 428 U.S. 52, 69 (1976), holding that the requirement of written spousal consent was unconstitutional in the abortion context, and affirming that holding in Planned Parenthood v. Casey, 505 U.S. 833 (1992). "A State may not give to a man the kind of dominion over his wife that parents exercise over their children." Id. at:898.

92 This type of approach is taken by the Davis court. See Davis v. Davis, 842 S.W.2d 588, 603-04 (Tenn. 1992) (holding that the potential father's financial and psychological interests in avoiding becoming an unwilling parent outweighed the potential mother's desire to donate the couple's frozen, fertilized eggs to an infertile couple). Such individual balancing would be valuable to a would-be father when a woman's physical burden of pregnancy is minimized by the provision of good medical care and where she will be relieved of the "burden" of child rearing after delivery by the father or another adoptive parent. To the extent that these mitigating factors are in aid of the interests of a father, they are equally unpersuasive in aid of the interests of the State, which, unlike the father in most jurisdictions, has "no affirmative [duty to] aid, even where such aid may be necessary to secure life, liberty, or property interests of which the government itself may not deprive the individual." DeShaney v. Winnebago County Dep't of Soc. Servs., 489 U.S. 189, 196 (1989). Of course, a balancing ap- 
of unwanted pregnancy and parenthood too great to impose on a woman, the Court declined a case-by-case inquiry in pre-viability abortions. ${ }^{93}$

Over the years, the doctrinal defense of the right to abortion never has been clear. In Planned Parenthood v. Casey, ${ }^{94}$ the Court's most recent analysis of the doctrinal basis of abortion rights, the Court declined to elucidate the source of the rights. ${ }^{95}$ Rather, the Court explained that abortion could be protected by the right to procreation which is inherent in the right to privacy. ${ }^{96}$ Alternatively, the right to abort a pregnancy could also be premised on the right to bodily autonomy which is itself a subset of the right to privacy. ${ }^{97}$ Lastly, the right to freedom from interference in obtaining an abortion could be understood as being a unique right. ${ }^{98}$

In Casey, it was unnecessary to isolate the source of the rights at issue because the results were the same no matter what the source. Analytical

proach in the abortion context would entail problems of proof and implementation. Those concerns, however, go to the scope of intrusion on the privacy of each party, not to the unique scope of a woman's right to abort.

${ }_{93}$ See Roe, 410 U.S. at 153 (listing many of the potential detriments imposed upon women in the event of an unwanted pregnancy).

94505 U.S. 833 (1992). In Casey, Roe was substantially retained but in a less structured form. Viability remains the dividing line, with a state prohibited from unduly burdening the right to abortion prior to that time in the absence of a compelling state interest. See id. at 846.

95 See id. at 857 ("It will be recognized, of course, that [Roe] stands at an intersection of two lines of decisions, but in whichever doctrinal category one reads the case, the result for present purposes will be the same.").

${ }^{96}$ See id. at 857 ("[Roe] is clearly in no jeopardy [if based on] ... liberty relating to intimate relationships, the family, and decisions about whether or not to beget or bear a child."). This right of privacy, however, has not precluded laws against fomication or prostitution. Consequently, the language linking the right of procreation with the notion of family is noteworthy.

${ }^{97}$ See id. at 857 (" $[R o e]$. . . may be ... a rule ... of personal autonomy and bodily integrity ...."). Note that, in the same vein, Skinner could represent simply the right to bodily integrity. See supra notes 55-65 and accompanying text (explaining Skinner). However, whether a woman's bodily integrity is implicated in the abortion context may not be dispositive. For example, although a state may not compel a surrogate mother to carry her pregnancy to term, it has been permitted, under the Fourth Amendment, to detain criminals until they excrete previously ingested contraband. See United States v. Montoya de Hernandez, 473 U.S. 531, 544 (1985) (permitting a six-hour detention without a warrant while officers waited for a woman to excrete 88 drug-filled balloons). The duration of such confinements and danger involved in waiting is not insignificant. See, e.g., United States v. Adekunle, 2 F.3d 559, 562 (5th Cir. 1993) (permitting a 100-hour detention, compulsory laxative use, and a monitored bowel movement); United States v. Odofin, 929 F.2d 56, 61 (2d Cir. 1991) (affirming a 24-day detention before a bowel movement). Such detention is permissible under the Fourth Amendment and, arguably, has less social justification than does the health and welfare of a child which is "fundamental to the very existence and survival of the race." Skinner v. Oklahoma, 316 U.S. 535, 541 (1942) ("The power to sterilize, if exercised, may have subtle, farreaching and devastating effects.").

98 See Casey, 505 U.S. at 857 ("[O]ne could classify [Roe] as sui generis."). 
distinctions, however, cannot remain as obscure in other contexts. The burgeoning growth of IVF technologies, for example, raises questions that directly implicate only the right of procreation ${ }^{99}$ - post-fertilization, preimplantation rights to decide "whether to bear or beget a child."

Moreover, the fact that IVF post-fetilization, pre-implantation disputes generally will arise in the context of divorce sharpens the focus on the relationship of marriage to the right of procreation. The connection between privacy rights and procreation is derived from the fundamental right to marriage. ${ }^{101}$ Further, the right to procreate is related to the subject matter of IVF-that is, children - as opposed to other arguably private behaviors such as drug use, gambling, or prostitution. When the right of procreation has been extended to single persons, it has been done with an emphasis on minimizing future responsibility and harm. In short, there is a constitutional basis for extending greater procreational rights to married persons (an exante right to have children or not) than to unmarried persons (only an exante right to decide not to have children). When consequences will not be shared by consenting adults, the Court has demonstrated an aversion to making one party pay the steep price of unwanted parenthood for one-time consensual behavior.

Perhaps, however, that says too much. After all, the Court removes decision-making power from even a married biological father when his wife becomes pregnant. She alone has the authority to perpetuate or terminate the pregnancy, apart from the father's wishes. Whether married or unmarried, the Court has found that the burdens of unwanted pregnancy and parenthood are too great to impose on one person. ${ }^{102}$ Moreover, a woman may choose to carry a pregnancy to term despite the objections of the biological father. Thus, the parenthood decision becomes irrevocable for a man at the time of intercourse and is not irrevocable for a woman until the much later stage of viability. In short, a combination of bodily integrity and irrevocable harm combine to divest a father of what might otherwise be his welldeveloped right to procreate. It seems harder to justify preference for nonmarital children in the face of one potential parent's opposition, even where no bodily integrity concerns arise. In the IVF context, no impending and irrevocable pregnancy forecloses the fundamentally life-altering decision

99 The right of bodily autonomy is not implicated by extra-corporeal embryos. Nor does history support IVF as its own right.

100 Eisenstadt v. Baird, 405 U.S. 438, 453 (1972).

101 See supra notes 61-71 and accompanying text.

102 See supra notes 91-93 and accompanying text (explaining that, in the case of an extant pregnancy, the more direct harm inheres to the woman and that a state may not give a man power that the state itself does not possess-the power to force pregnancy and birth). 
regarding whether or not to bear a child. In fact, unwanted parenthood outside of marriage is still a burden which ought not be imposed. ${ }^{103}$

\section{Rights of Function: Control and Companionship of Children}

The preceding discussion centered on the rights of consenting adults to marry, to divorce, and to control certain procreative decisions. There is also a line of cases that deals more particularly with the rights and duties of parents in their relations with their children.

The Court has observed, and reiterated, that "the custody, care and nurture of the child reside first in the parents, whose primary function and freedom include preparation for obligations the State can neither supply nor hinder." "104 In several cases, for example, the Court has recognized a parent's right to resist the standardizing effect of a public school education on his or her children. ${ }^{105}$

Also derived from the rights of the family are the rights of unwed, biological fathers to block the adoptions of their genetic offspring. ${ }^{106}$ In short,

103 The importance of genetic connection, demonstrated by the large enrollment at IVF clinics, should not be denied. See Barbara Bennett Woodhouse, Hatching the Egg: A ChildCentered Perspective on Parents' Rights, 14 CARDOZO L. REv. 1747, 1778 (1993). Parents separated from known children experience a loss of connection and development. See MIRIAM GALPER COHEN, LONG-DISTANCE PARENTING 21 (1989) ("Without that connection, both parents and children fail to develop a part of themselves."). "After divorce then the structures which integrate the diverse aspirations of parents into a coherent and workable whole are at best problematic .... This process is inevitably a painful one, touching as it does on fundamentals of identity and emotion." BOB SIMPSON, CHANGING FAMIIIES: AN ETHNOGRAPHIC APPROACH TO DIVORCE AND SEPARATTON 75 (1998); see also id. at 52-53 (explaining vitriolic divorce as derived, in part, from parental self-identification with "future identity of offspring"). It has been shown that birth parents who surrender a child for adoption experience "posttraumatic stress" during an often isolated and extended grieving period. See Davis v. Davis, 842 S.W.2d 588 (Tenn. 1992) (citing studies regarding parental loss); JOYCE MAGUIRE PAVAO, THE FAMILY OF ADOPTION 10 (1998) ("Many birth parents spend the early period, after the surrender, as do people who have other kinds of posttraumatic stress."). Other commentators have identified the extreme stress occassioned by the pressures of unwanted children outside of marriage. See Dehmel, supra note 4, at 1402 (describing psychological burdens); Robertson, supra note 25, at 479 (suggesting psychological loss).

${ }_{104}$ Quilloin v. Walcott, 434 U.S. 246, 255 (1978) (quoting Prince v. Massachusetts, 321 U.S. 158, $166(1944))$.

${ }^{105}$ See Wisconsin v. Yoder, 406 U.S. 205, 229-34 (1972) (holding unconstitutional a state law which made it a criminal offense to fail to send one's children to school until the age of sixteen as applied to the Old Order Amish, whose rights to free exercise of religion would be violated if their children were sent to public school in accordance with the law); Meyer v. Nebraska, 262 U.S. 390, 399-400 (1923) (recognizing the right of an individual to receive instruction in a modern, foreign language and holding that a law which denied that right was contrary to the Due Process Clause of the Fourteenth Amendment).

${ }^{106}$ See Caban v. Mohammed, 441 U.S. 380, 394 (1979) (holding that the Equal Protection Clause prohibited a statute giving an unwed, biological mother the right to block adoption 
the cases acknowledge the importance of biological ties, but require more: an unwed father must demonstrate "a full commitment to parenthood by developing a complete and permanent relationship with his child."107 The Supreme Court has recognized that a state may extend rights to married fathers that it does not extend to unmarried fathers, on the assumption that married fathers explicitly incur obligations to a child, while unmarried fathers do not. $^{108}$ Biology, then, is of secondary import to social relationship. Courts

by withholding consent but extending no similar protection to an unwed father who had demonstrated a paternal interest in the child); Stanley v. Illinois, 405 U.S. 645, 657-58 (1972) (holding that the Due Process Clause of the Fourteenth Amendment prohibits a state from terminating the parental rights of an unwed, biological parent without notice and a hearing). But see Michael H. v. Gerald D., 491 U.S. 110, 129-32 (1989) (holding that a law establishing a presumption that a child bom to a married woman is a child of the marriage, which may be rebutted only by the husband or wife but not the putative biological father, was a reasonable means of supporting the marital relation and did not infringe the due process rights of either the unwed, biological father or the child); Lehr v. Robertson, 463 U.S. 248, 262-63, 267-68 (1983) (holding that an adoption by a biological mother and her husband, without notice to the biological father, was not unconstitutional under either the Due Process or Equal Protection Clauses where the biological father had asserted almost no parental interest in the child); Quilloin, 434 U.S. at 255-56 (holding that neither due process nor equal protection was violated by a statute requiring only the biological mother's consent to the adoption of a child born out of wedlock, where the biological father had made no attempt to obtain actual or legal custody for 11 years and where adoption was in the best interests of the child).

${ }^{107}$ Ardis L. Campbell, Annotation, Rights of Unwed Father to Obstruct Adoption of His Child by Withholding Consent, 61 A.L.R. 5TH 151, 178 (1998); see also id. at 178-80 (summarizing Lehr, 463 U.S. 248; Caban, 441 U.S. 380; Quilloin, 434 U.S. 246; and Stanley, 405 U.S. 645). Campbell notes that courts generally hold that where a relationship exists between a father and a child, the father has the right to refuse consent to the child's adoption. See id. at 180. Campbell further notes that courts split as to the importance of a father's pre-birth assistance to a mother and fetus, some courts finding it irrelevant to the issue of the father's consent and others finding it a prerequisite to his right of refusal. See id. at 178.

Distinguishing IVF custody disputes, of course, requires no more than realizing that all prior case law addresses these questions only in the context of viable, ongoing pregnancies. Further, IVF disputes pose an interesting question as to the importance of "support": in the custody disputes, the parties are divorcing. Presumably, they ought not be compelled to be together. See Boddie v. Connecticut, 401 U.S. 371, 383 (1971) (holding that due process prohibits a state from denying access to a divorce on the basis of inability to pay court fees and costs). The requirement of support, however, would require continued interaction. Moreover, if a couple contracted for a man to keep the cryopreserved preembryos, would his ex-wife have a duty to support him or the woman-whether new wife, girlfriend, or surrogate-who carried the genetic material, half of which was the ex-wife's? It is anomolous to translate a doctrine developed to accommodate extant pregnancies and family rights to a situation where no one is pregnant and the family is dissolving.

108 See Quilloin, 434 U.S. at 255 (holding that a father who made no effort to seek custody of his child or to legitimate the child over an 11-year period was not deprived of due process or equal protection when the child was adopted without his consent). As explained, unmarried fathers may preserve their rights by acting like fathers. Married fathers are presumed to act like fathers, having assumed the responsibilities of marriage and parenthood. In Lehr, 463 U.S. at 267-68, the Court upheld a New York statute which guaranteed notice and the right to veto an adoption to all unwed mothers, but only to those unwed putative fathers who 
favor parents who assume responsibility within the state-sanctioned and sacred confines of marriage. Read one way, these decisions could support the right to implant the embryo: the State would be rewarding the parent who sought custody and responsibility. The critical distinction, however, is that prior cases of custody and control arose in the context of an existing constitutional person-a child. The question becomes whether IVF disputes look more like the necessary adjudication of parental rights and responsibilities attendant to the irrevocable fact of a constitutional person (a child) or look more like decisions of single individuals to avoid the emotional, financial, and social harms of unwanted parenthood.

Having articulated a privacy preference for marriage and a limit on biology drawn by consequences, the IVF disputes present an unmarried couple with a nonviable embryo outside the body.

\section{IVF CUSTODY BATTLES}

IVF makes pregnancy possible where intercourse does not. Further, cryopreservation of preembryos enables a delay between the decision to fertilize an egg and the time of implantation of the egg. Also, the potential for life inherent in a preembryo generally entitles it to more consideration than property, but less than a constitutional "person." Finally, the Constitution, under the rubrics of privacy and family, protects the rights of procreation and parenthood, particularly within the marital relationship.

Two state courts of last resort have taken notice of these legal doctrines within the factual context of custody disputes over frozen preembryos. ${ }^{109}$ The following sections present those cases to facilitate analysis of custody disputes generally.

\section{A. Custody in General: Davis v. Davis ${ }^{110}$}

Mary Sue and Junior Lewis Davis met and married while both were in the Army. ${ }^{111}$ After a series of painful and dangerous tubal pregnancies forced Mary Sue to have both her fallopian tubes ligated, the couple tried to

registered with the state. The Court reasoned that the disparate treatment of the different parents was fairly based on their different levels of commitment to the child, and that the state had provided a reasonable means for unwed putative fathers to safeguard their rights. See id. at 264-67.

109 See Kass v. Kass, 696 N.E.2d 174 (N.Y. 1998) (involving a custody dispute between a divorcing couple over their frozen embryos); Davis v. Davis, 842 S.W.2d 588 (Tenn. 1992) (same).

110842 S.W.2d 588 (Tenn. 1992), aff'g No. 180, 1990 WL 130807 (Tenn. Ct. App. Sept. 13, 1990), rev'g No. E-14496, 1989 WL 140495 (Tenn. Cir. Ct. Sept. 21, 1989).

111 See id. at 591. 
adopt. ${ }^{112}$ A change of heart by the birthmother in one instance, ${ }^{113}$ and the prohibitive cost of adoption in others, ${ }^{114}$ left the Davises unable to become parents by adoption. Desiring still to become parents, the couple pursued IVF. ${ }^{115}$ The process was painful and demanding for Mary Sue: each implantation required the aspiration of eggs, with the attendant anesthesia, injections, and testing. ${ }^{116}$

After some time, cryopreservation became available and the burden of the aspirations was reduced, since multiple eggs could be aspirated and saved for later implantation. ${ }^{117}$ In one aspiration, Mary Sue produced nine eggs, which were then fertilized with Junior's sperm. ${ }^{\text {l18 }}$ Several were implanted, and the rest were cryopreserved for future use. ${ }^{119}$ The first implantation failed to result in pregnancy, and, shortly thereafter, Junior filed for divorce. ${ }^{120}$ The issue dividing the couple in the proceedings was the disposition of the fertilized embryos. ${ }^{121}$

At trial, the judge heard testimony that "human life begins at the moment of conception."122 Finding that the cryopreserved preembryos were "children in vitro," 123 the court concluded that it was in the best interest ${ }^{124}$ of the "children" to be born, rather than destroyed in vitro. ${ }^{125}$

${ }_{113}^{112}$ See id.

115 See id. ("In vitro fertilization became essentially the only option for the Davises to pursue in their attempt to become parents.").

116 The court related the facts:

Despite her fear of needles ... Mary Sue underwent the month of subcutaneous injections ... and the eight days of intermuscular injections .... She was anesthetized five times for the aspiration procedure .... Forty-eight to [seventy-two] hours after each aspiration, she returned for transfer back to her uterus, only to receive a negative pregnancy test result each time.

Id. at 591-92.

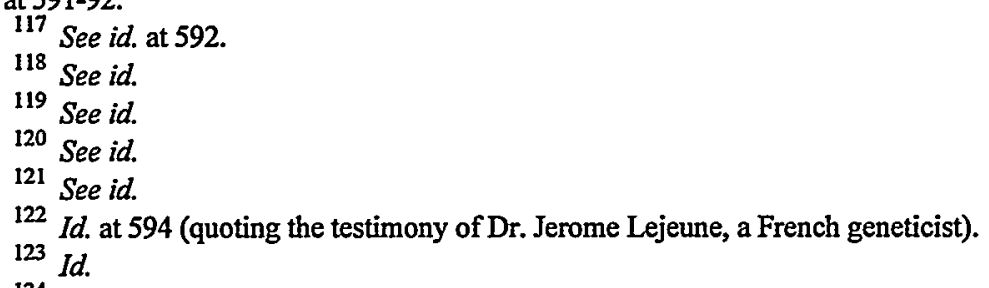

124 The "best interest" analysis is standard in custody disputes between biological parents seeking custody in a divorce proceeding. See HARRIS ET AL., supra note 65, at 589 (noting the legal development by which the "best interests of the child become a judicial yardstick used to measure all claims for children" (internal quotations omitted)); Ebrahim J. Kermani, Issues of Child Custody and Our Moral Values in the Era of New Medical Technology, $31 \mathrm{~J}$. AM. ACAD. CHIID \& ADOLESCENT PSYCHIATRY 533, 533 (1992) (noting that the best interest of the child "still plays an essential role in the settlement of custody disputes").

125 See Davis, 842 S.W.2d at 594. 
Mary Sue sought to implant the preembryos in herself and was awarded custody. ${ }^{126}$

The intermediate appellate court rejected the notion that life begins at conception. ${ }^{127}$ The court applied an implicit property analysis and granted joint custody to Mary Sue and Junior Davis. ${ }^{128}$ That decision was appealed, and the Supreme Court of Tennessee agreed to decide the matter. Meanwhile, Mary Sue remarried and no longer sought custody for herself, but rather, sought custody so that she might donate the preembryos to another couple. $^{129}$

The Supreme Court of Tennessee held that the preembryos occupied "an interim category [between person and property] that entitles them to special respect because of their potential for human life."130 The court said that any agreement between the Davises regarding disposition in the event of disagreement would have been presumed valid. ${ }^{131}$ In the absence of such an agreement, however, the court declined to "decide [the] case on the basis of implied contract or the reliance doctrine."132 Rather, the court balanced two competing constitutional interests that it found within the right to privacy: ${ }^{133}$ the right to procreate and the right not to procreate. ${ }^{134}$

The court balanced Junior's expected financial and unique psychological burdens ${ }^{135}$ if forced to become an unwilling parent against Mary Sue's

126 See id.

127 See id. (stating that "[t]he Court of Appeals explicitly rejected the trial judge's reasoning, as well as the result" and that "the argument that "human life begins at the moment of conception" had "been abandoned by the appellant, despite her success with it in the trial court" (footnote omitted)).

${ }^{128}$ See id. at 595-96.

129 See id. at 590.

130 Id. at 597; see supra Part II.A (discussing the possibile classifications for a preembryo from which the court could choose).

${ }^{131}$ See Davis, 842 S.W.2d at 597 ("[A]n agreement regarding disposition of any untransferred preembryos in the event of contingencies ... should be presumed valid and should be enforced as between the progenitors.").

${ }_{132} I d$. at 598 (footnote omitted).

${ }^{133}$ See id. ("[T] preembryos, but whether the parties will become parents.... [T] he answer to this dilemma turns on the parties' exercise of their constitutional right to privacy.").

${ }^{134}$ See id. at 600-01 (holding that, under the state constitution, the right to privacy encompasses the right to procreation, and analyzing federal cases to demonstrate that "procreational autonomy is composed of two rights of equal significance-the right to procreate and the right to avoid procreation").

${ }^{135}$ See id. at 603-04 ('Junior Davis testified that, as a boy, he had severe problems caused by separation from his parents.... In light of his boyhood experiences, [he] is vehemently opposed to fathering a child that would not live with both parents."). 
desire to donate the eggs to an infertile couple. ${ }^{136}$ The court held that Junior's interests weighed more heavily. ${ }^{137}$ The court articulated a three-part inquiry for resolving disputes over the disposition of frozen preembryos. First, a court should honor the "preferences of the progenitors." where unclear, the court should give effect to the prior agreement of the parties. $^{139}$ Finally, and absent prior agreement or preference, the court should weigh the relative interests of the parties with the understanding that "the party wishing to avoid procreation should prevail, assuming that the other party has a reasonable possibility of achieving parenthood by means other than use of the preembryos in question. ... But, the rule does not contemplate the creation of an automatic veto . ...,140

The Davis court noted that it would have confronted a closer case "if Mary Sue Davis were seeking to use the preembryos herself ... [because] she could not achieve parenthood by any other reasonable means."141 That closer case arose several years later in the state of New York.

\section{B. A Closer Case: Kass v. Kass ${ }^{142}$}

In 1993, Maureen Kass sought custody of five fertilized, cryopreserved pre-zygotes $^{143}$ that remained from IVF procedures that she and her husband,

136 See id. at 604 ("Refusal to permit donation ... would impose on her the burden of knowing that the lengthy IVF procedures she underwent were futile, and that the preembryos to which she contributed genetic material would never become children.").

${ }^{137}$ See id. ("Donation, if a child came of it, would rob him twice-his procreational autonomy would be defeated and his relationship with his offspring would be prohibited.").

138 Id. To avoid redundancy with the second prong, the "preference of the progenitors" must mean the preference of the parties at the time of divorce. That understanding, however, does not seem well suited to custody battles where the fact of the dispute indicates the lack of a present agreement. Moreover, effecting the preference of the progenitors may not conclusively resolve the ultimate question of custody of a resulting child. See infra Part IV.

139 See Davis, 842 S.W.2d at 604 ("If their wishes cannot be ascertained, or if there is dispute, then their prior agreement concerning disposition should be carried out.").

${ }^{140} I d$. It is noteworthy that if the parties ever had agreed, even years past and under different circumstances, then the court would not weigh the parties' present interests. See id. at 597 ("[T] he parties' initial informed consent to IVF procedures will often not be truly informed because of ... all the turns that events may take ... [b]ut, in absence of ... [agreed upon] modification[s], we conclude that their prior agreement should be considered binding.").

141 Id. at 604.

142696 N.E.2d 174 (N.Y. 1998), aff'g 663 N.Y.S.2d 581 (App. Div. 1997), rev'g No. 19658/93, 1995 WL 110368 (N.Y. Sup. Ct. Jan. 18, 1995) (unpublished opinion).

143 The court adopted the terms used in the agreement signed by the couple without inquiring into the biological accuracy of the terms. For simplicity, the term "pre-zygote" is used here as well. There is, of course, a biological difference between a zygote, which is the onecelled stage after the sperm fertilizes the egg but before cell division, and a preembryo, which encompasses the early cell division, lasting approximately fourteen days after fertilization. 
Steven, had undergone. ${ }^{144}$ For three years following her 1988 marriage, Maureen Kass underwent aspiration five times and unsuccessful implantation nine times. ${ }^{145}$ In May 1993, the Kasses attempted to implant their prezygotes into Maureen's sister, who agreed to carry a resulting pregnancy to term on behalf of the couple. ${ }^{146}$ The implantation did not result in a pregnancy. Subsequently, the couple prepared a document for an uncontested divorce. ${ }^{147}$ The document provided for the disposition of the five remaining pre-zygotes according to an informed consent document that the parties had signed upon enrollment in an IVF program. ${ }^{148}$ Three weeks later, however, Maureen communicated her opposition to the destruction of the prezygotes. ${ }^{149}$ Steven, on the other hand, sought to have the pre-zygotes donated to science, not wanting to become a parent outside of marriage. ${ }^{150}$

At trial, the judge found that the informed consent document controlled disposition only to the extent that it provided that in the event of divorce, "distribution would be subject to the directives of the divorce court." trial court held that a woman's procreative rights with respect to cryopreserved pre-zygotes were the same as her rights with respect to a nonviable fetus in utero, and that the woman's rights were exclusive of the man's rights. ${ }^{152}$ The trial court granted exclusive custody and rights to Maureen Kass. ${ }^{153}$ The judgment was stayed pending appeal. ${ }^{154}$

A divided intermediate appellate court reversed. ${ }^{155}$ The five appellate judges agreed on two propositions. First, they concluded that "[a] woman's established right to exercise virtually exclusive control over her own body is

See Veeck, supra note 16, at 2355 (providing definitions of several terms, including "prezygote" and "zygote").

144 See Kass, 696 N.E.2d at 177.

145 See id. at 175-76. To be clear, this means that Maureen Kass experienced surgical intrusion on 14 occasions and nine failed pregnancy attempts within a three-year period of time.

146 See id. at 177.

147 See id.

148 See id. (stating that the disposition of the pre-zygotes according to the informed consent form was donation to research and that "neither Maureen Kass[,] Steve Kass or anyone else will lay claim to custody of these pre-zygotes").

149 See id.

150 See id.

151 Kass v. Kass, No. 19658/93, 1995 WL 110368, at *4 (N.Y. Sup. Ct. Jan. 18, 1995) (unpublished opinion), rev'd, 663 N.Y.S.2d 581, 585 (App. Div. 1997), aff'd, 696 N.E.2d 174.

152 See id. at *3 (observing that for "in vitro fertilizations the right of the wife must be considered paramount and her wishes with respect to disposition must prevail").

153 See id. at *5.

154 See Kass, 663 N.Y.S. $2 d$ at 585.

155 See id. at 590. 
not implicated... until ... implantation actually occurs."156 Second, the court unanimously concluded that "the first . . . inquiry should be directed at whether the parties have made an expression of mutual intent which governs the disposition of the pre-zygotes under the circumstances in which the parties find themselves.",157

The plurality found that the informed consent document was evidence of the parties' intent to donate the pre-zygotes for research if they were unable to agree. ${ }^{158}$ The plurality also found the consent document to be dispositive because the case involved "intensely personal and essentially private matters which are appropriately resolved by the prospective parents rather than the courts." 159 The concurring judge stated that the informed consent document was ambiguous as to the disposition of the pre-zygotes in the event of the parties' disagreement. ${ }^{160}$ The concurring opinion asserted that "the objecting party, except in the most exceptional circumstances, should be able to veto a former spouse's proposed implantation."161 The concurring judge did not think that Maureen Kass had proved such exceptional circumstances. ${ }^{162}$ Two dissenting judges agreed with the concurring opinion in that the informed consent document was not a clear statement of the parties' intent. ${ }^{163}$ The dissent would have remanded the case to the trial court for an inquiry into the interests, positions, and burdens of the parties. $^{164}$

The New York Court of Appeals, the state's high court, affirmed ${ }^{165}$ the plurality holding. The court first held that a woman's rights of privacy and

156 Id. at 586 (citing Davis v. Davis, 842 S.W.2d 588, 601 (Tenn. 1992)).

157 Id.

158

See id. at 587.

159 Id. at 590.

${ }^{160}$ See id. at 592 (Friedman, J., concurring) ("[T] of multiple and conflicting interpretations, with the result that, in my opinion, it cannot logically be relied upon to resolve the instant dispute.").

${ }_{161}$ Id. (Friedman, J., concurring)

162 See id. at 593-94 (Friedman, J., concurring) ("[T]he plaintiff has effectively proven on the instant record that she could not make the necessary showing of exigency even if she were afforded the opportunity.").

${ }^{163}$ See id. at 594 (Miller, J., dissenting) (disputing the plurality's contention that the "agreement in issue, by any stretch of the imagination, reflects the intent of these parties to destroy their pre-zygotes in the event of divorce").

${ }^{164}$ See id. at 599-602 (relying on the assertion of the Davis court that an analysis should "consider the positions of the parties, the significance of their interests and the relative burdens that will be imposed by differing resolutions" (quoting Davis v. Davis, 842 S.W.2d 588, 603 (Tenn. 1992))).

${ }^{165}$ See Kass v. Kass, 696 N.E.2d 174, 175 (N.Y. 1998), aff'g 663 N.Y.S.2d 581 (N.Y. Sup. Ct. 1997). 
bodily integrity were not implicated in the dispute over the pre-zygotes. ${ }^{166}$ Further, the court observed that the pre-zygotes were not "persons" in the constitutional sense. ${ }^{167}$ The court suggested that "[a]greements between progenitors, or gamete donors, regarding disposition of their pre-zygotes should generally be presumed valid and binding, and enforced in any dispute between them." 168 Analysis of the agreement led the court to conclude that the agreement was clear and dispositive-the pre-zygotes would be donated to research if the parties could not otherwise agree. ${ }^{169}$

\section{After Davis and Kass: What Next?}

Both the Kass and Davis courts suggested that, due to the intimate nature of the subject matter and the deference to privacy in matters of procreation, private disposition agreements would be enforced. The Kass court unanimously construed a document to be unambiguous, the same document sharply dividing five judges at the intermediate appellate level. ${ }^{170}$ The Davis court, in the absence of a preferred prior agreement or contract, conducted an inquiry into the rights and interests of the parties. ${ }^{171}$ Both courts ordered judgment for the party opposing implantation.

Three questions arise from these two decisions. First, should prior agreements by the parties be given legal effect when the parties divorce or disagree? Second, if prior agreements are unenforceable, either as a matter of law or construction, how should the disposition determination be made? Third, does the right to procreate shed any light on the legal rights of the parties in IVF custody disputes? The following Parts address these questions in turn.

\section{DEFERENCE TO CONTRACT OR INFORMED CONSENT AGREEMENTS}

The Davis and Kass courts agreed that the intent of the parties, as expressed in either a contract or an informed consent agreement, should con-

166 See id. at 179.

167 See id.

168 Id. at 180 (citing Davis, 842 S.W.2d at 597).

169 See id. at 180-82 (applying "common-law principles governing contract interpretation").

${ }^{170}$ See supra notes 155-69 and accompanying text (discussing the opinions of the five appellate judges as well as the New York Court of Appeals affirmation of the intermediate appellate court's plurality opinion, which found the consent document to be unambiguous).

${ }^{171}$ See supra notes 130-40 and accompanying text (discussing the balancing test undertaken by the Davis court to decide which of the parties would prevail). 
trol the disposition of unimplanted, fertilized eggs. ${ }^{172}$ For a variety of reasons, this Comment argues that such deference is inappropriate in the context of IVF.

\section{A. Psychological Barriers to Contract}

The delicate subject matter of a prior IVF agreement-children and parenthood-and the psychological barriers to rational thinking about these matters in the IVF context, likely will cause the contract to be nonrepresentative of the parties' intent. ${ }^{173}$ ' "II]nfertility patients pursue treatment with a tenacity equal to that of cancer patients .... The need to pursue and succeed in treatment can therefore be powerful and profound ....,"174 Infertility can place an enormous degree of stress on individuals and their marriages. ${ }^{175}$ The pressures and expectations involved often mean that a couple will not make decisions in their usual and customary way. ${ }^{176}$ Still another

172 See supra note 168 and accompanying text; see also Davis, 842 S.W.2d at 597 (stating in dicta that "an agreement regarding disposition of any ... preembryos in the event of contingencies ... should be presumed valid and should be enforced as between the progenitors").

${ }^{173}$ See Davis, 842 S.W.2d at 597 ('[T] he parties' initial 'informed consent' to IVF procedures will often not be truly informed because of the near impossibility of anticipating, emotionally and psychologically, all the turns that events may take ...."); Applegarth, supra note 46, at 1958 ("[M]any couples are ill prepared to cope with the uncertainties, fears, and potential losses that infertility entails."); Daar, supra note 11, at 629 ("Psychological studies ... suggest that even with accurate disclosure, patients may not understand the information provided or its implications." (citing Marc A. Rodwin, Physicians' Conflicts of Interest: The Limitations of Disclosure, 321 NEW ENG. J. MED. 1405, 1405 (1989))); Maranto, supra note 7 , at 18 (discussing a practitioner's observation that couples do not know how they will feel about these matters); Robertson, supra note 25, at 475 ("Because so many contingencies could intervene to change original plans, creation of embryos alone should not be taken as an irrevocable commitment to reproduction.").

174 Applegarth, supra note 46, at 1961 (citation omitted). "[A] unique, dichotomous psychological profile" has also been observed among those seeking treatment: they combine a high degree of information regarding the technical aspects of fertility treatment with an unrealistically high expectation of success. See Daar, supra note 11, at 629 \& nn.110-12.

175 See Applegarth, supra note 46, at 1954-62 (describing the emotional response to infertility in individuals and couples); Rutter, supra note 7, at 70 ("[T]echnofertility can create such stress in a couple that it can come close to undoing their relationship-the raison d'être for baby-making.").

176 "For many patients and their partners, infertility becomes a part of every waking moment. It dictates decisions .... In effect, many patients often describe themselves as feeling 'stuck' or as seeing their lives as out of balance and out of control." Applegarth, supra note 46, at 1955. This "stuck" feeling may make a couple overly susceptible to cooperating with an infertility facility, abiding by its policies even though the couple has doubts:

[F] ear [of being told to leave a facility and give up] may lead to extreme compliance on the part of the patients.... [C]ompliance may contribute to a feeling of being victimized or misunderstood by the physician and medical support staff. As treatment continues, patients sometimes begin to feel less and less a part of the decision- 
barrier to the parties coming to a real agreement on the issues is the communication gap that often arises when a couple is confronting infertility. ${ }^{177}$ In fact, the zealous pursuit of IVF may mask and exacerbate underlying marital discord. ${ }^{178}$

A strong argument has been made that, due to similar cognitive dissonance and psychological resistance, prenuptial agreements are inherently suspect. ${ }^{179}$ Despite this argument, states clearly prefer private ordering within the marriage relationship and at the time of divorce. ${ }^{180}$ Conse-

making process.

Id. at 1961; see also Rutter, supra note 7, at 67-68 (explaining that, in the infertility context, technical considerations tend to dominate couples' decision-making processes and that couples often lose focus on everything else in life).

${ }^{177}$ Applegarth suggests that "gender-specific responses to infertility ... may at times undermine the intimacy and emotional bond that most couples experience." Applegarth, supra note 46, at 1957. She further suggests that partners may feel "isolated from one another" and may experience "periods in which [they are] unable to work through differences with respect to treatment decisions." Id.; see also Rutter, supra note 7, at 66 (describing both the typical male and female responses as isolation enhanced by an inability to share feelings). In this light, the assumption that any agreement represents a "meeting of the minds" of the couple is highly suspect.

178 It is possible that couples seeking fertility treatment have a higher likelihood of dissolution, as infertility reinforces marital discord and marital discord leads to desperate expectations from fertility treatment. Compare Panitch, supra note 8, at 546 \& n.24 ("These couples often find the inability to bear children to be a great and powerful loss, causing 'isolation, guilt, marital strife, and intense assaults on feelings of self-worth."' (quoting Robertson, supra note 7, at 945)), with Davis, 842 S.W.2d at 592 (noting that Junior Davis "testified that he had known that their marriage 'was not very stable' for a year or more, but had hoped that the birth of a child would improve their relationship"). See generally Applegarth, supra note 46, at 1954-67 (detailing the complex interrelationship between infertility, social structure, and social response and advocating a more sophisticated role for counselors).

There is some evidence that "infertile couples going for fertility treatment tend to have higher rates of marital satisfaction than the rest of the population." Rutter, supra note 7, at 67. This evidence is not responsive to the concerns of this Comment. The question is not how to handle couples who agree or whose marriages survive. Rather, it is what to do when they disagree and divorce. As the director of the study discussed above acknowledges, what is important is whether, independently, the couple has the "skills to address their problem"--infertility and its disappointments. Id.

179 See Barbara Ann Atwood, Ten Years Later: Lingering Concerns About the Uniform Premarital Agreement Act, 19 J. LEGIS. 127, $135 \&$ nn.34-36 (1993) (explaining that people irrationally expect marriage to last forever). This unrealistic expectation is similar to the cognitive dissonance exhibited by IVF participants. See supra notes 173-82 and accompanying text (discussing the extreme mental stress experienced by individuals and couples undergoing infertility treatment and its effect on their decision-making ability); see also Allison A. Marston, Note, Planning for Love: The Politics of Prenuptial Agreements, 49 STAN. L. REV. 887, 900-01 \& nn.104-06 (1997) (discussing a study which revealed a "significant discrepancy between what most couples know about divorce and what they think their chances are of getting divorced").

${ }_{180}$ See Marston, supra note 179 , at 898 \& nn.83-84 (explaining that "prenuptial agreements that include divorce provisions are now generally enforceable in all states"); id. at 903 
quently, in modern jurisprudence, prenuptial agreements generally are enforceable with respect to property allocation and maintenance decrees despite cognitive dissonance. ${ }^{181}$ Further, a number of courts have pointed to "no-fault" divorce statutes as evidence that public policy recognizes that divorce is a reality which prospective spouses ought to anticipate and for which they may contract. ${ }^{182}$

Because, however, prenuptial agreements generally are not binding with respect to custody or support obligations to children, ${ }^{183}$ their enforceability is less relevant to IVF disputes, in which potential children are the source of disagreement. The difference rightly has been characterized by other commentators as essential. ${ }^{184}$

\& nn.121-22 (explaining the trend towards a state preference for contract as part of a larger trend in family law "from public to private ordering of behavior" and suggesting even more broadly that contract replaces status in an era of social upheaval). But see Atwood, supra note 179, at 154 (arguing that the Uniform Premarital Agreement Act policy, which favors strict enforcement of prenuptial agreements, is more likely to disadvantage women than men).

181 See Robert Roy, Annotation, Modern Status of Views as to Validity of Premarital Agreements Contemplating Divorce or Separation, 53 A.L.R. 4TH 22, 29 (1987) (explaining that "a majority of the states recently addressing the issue, whether by judicial decision or by legislation as revealed in reported cases, no longer hold such agreements inherently void, invalidating only those agreements found defective in execution or result"); see also Gant v. Gant, 329 S.E.2d 106, 116 (W. Va. 1985) (holding that premarital agreements regarding property and spousal support are not inherently void and giving effect to a contract between a couple who, each having been married once, might not have married again in the absence of the ability to structure their expectations); UNIF. MARTTAL PROP. ACT $\S \S 3,10,9 A$ U.L.A. 115, 131 (1998) (setting out rules to govern marital property agreements); UNIF. MARRIAGE \& DIVORCE ACT $\S 307$ (amended 1973), 9A U.L.A. 288 (1998) (recommending that courts should take into consideration any antenuptial agreements when deciding apportionment of resources).

${ }^{182}$ See Roy, supra note 181 , at $52-55$ (summarizing several cases and noting that shifts in public policy regarding divorce influenced the reversal of judicial disfavor of premarital agreements contemplating divorce).

${ }^{183}$ See, e.g., Edwardson v. Edwardson, 798 S.W.2d 941, 945-46 (Ky. 1990) (holding that prenuptial agreements in contemplation of divorce are valid where they are formed with full disclosure, where they are not unconscionable at the time of enforcement, and where they are applicable only to property and maintenance); Campbell v. Moore, I S.E.2d 784, 793-96 (S.C. 1939) (confirming that a premarital agreement, which limited a prospective husband's support of his child, violated public policy because society has an interest in the fulfillment of the child support obligation); Gant, 329 S.E.2d at 116 (holding that, although premarital agreements settling property and spousal support rights in the event of divorce are presumptively valid, the birth of children is a factor a court would consider in deciding whether to enforce such an agreement); Atwood, supra note 179, at 151 (noting that in the case of separation agreements, provisions relating to "child support, custody, or visitation remain subject to judicial scrutiny under a reasonableness standard").

184 See Annas, supra note 7, at 936 (" $[N]$ o court has ever forced any person to fulfill the terms of a surrogate-mother contract, a custody contract, or a marriage contract by requiring that the parties be bound regardless of their current wishes or the best interests of the children involved."); Ellen M. Moskowitz, Some Things Don't Belong in Contracts, NAT'L L.J., June 
State adoption law is also helpful in determining the legal rules surrounding IVF disposition disputes. The general rule is that when a natural parent consents to the adoption of his or her biological child, all rights of the natural parent are terminated. ${ }^{185}$ Nonetheless, a pre-birth consent to adoption is not binding in many states. ${ }^{186}$ The concern underlying such a policy seems less one of the child's best interest or concern for repose and more one animated by a belief that, until holding a child, a waiver of parental rights cannot be knowing, voluntary, or intelligent. These concerns underly contracts in the IVF context. "When they undertake IVF, couples cannot reasonably be expected to know how they will feel about their embryos down the line."187

There is consistency here. First, contracts regarding future children generally are not binding. Second, agreements about the future care of children generally are not binding. Third, once an adoption is finalized, it generally is binding but less often so where one former spouse disputes the

8, 1998, at A25 ("Child custody agreements depend on court review and approval .... Antenuptial agreements are enforceable, but not with respect to reproduction.").

185 See Russell G. Donaldson, Annotation, Natural Parent's Parental Rights As Affected by Consent to Child's Adoption by Other Natural Parent, 37 A.L.R. 4TH 724, 725-26 (1985) ("The weight of authority to [terminate all rights of the natural parent upon consenting to have his or her child adopted] is so overwhelming that a collection of individual case citations in support thereof would be wasteful and uninformative.").

In several cases, however, courts read the relevant statutes to create an exception for cases in which one natural parent adopted the child with the consent of the other natural parent. See id. at 726 (noting that a few courts, in "exceptional circumstances," have found that a natural parent's consent to the adoption by the other natural parent did not terminate all of the parental rights of the first parent). Cases cited explain that those exceptional circumstances involve possible fraud and legal malpractice, see In re Jessica W., 453 A.2d 1297, 1300-01 (N.H. 1982) (holding that if a natural mother can show that she permitted an adoption by the natural father based on the father's material misrepresentations and an attorney's ethical violations, then the natural mother may retain parental rights despite the absence of a statutory exception for fraud in the relevant statute), circumstances where one party was unable legally to marry the other, see In re Adoption of a Child by A.R., 378 A.2d 87, $89-90$ (N.J. Union County Ct. 1977) (finding that since the purpose of the adoption was simply so that the child of a legally incompetent natural mother could inherit from the natural father, the adoption by the natural father did not terminate the natural mother's rights), and circumstances where parents who agreed that "marriage would be harmful" deliberately conceived out of wedlock, see In re A.J.J., 438 N.Y.S.2d 444, 445 (Sup. Ct. 1981) (finding that an adoption by the natural father making the child his legitimate heir, while still allowing the mother to retain her parental rights, was permissible in order to serve the best interests of the child).

${ }^{186}$ See Moskowitz, supra note 184, at A25 ("A pre-birth decision to surrender a child for adoption is unenforceable."); see also HARRIS ET AL., supra note 65, at 1173 (explaining that some states bar consent to adopt before birth and that some impose statutory time limits after birth).

187 See Maranto, supra note 7, at 18 (explaining that a couple's informed consent to storing embryos for only a limited period of time may really be something less because of unforeseen emotional attachment). 
other. Underlying these rules is an awareness of the magnitude of the parenthood decision, the interests of an independent third party (the child), and the interests of the State in repose.

\section{B. Social Obstacles to Contract}

Even if the psychological barriers to contract are surmounted, there still exist social considerations which counsel against favoring contract in the IVF context.

First, the effect of state child custody laws may be to undo decisions which uphold contracts that favor implantation. That is, a contract may assign one parent custody of the embryos. If implanted successfully, however, the noncustodial donor will potentially complicate actual child custody.

A brief overview of state laws will clarify this point. With respect to custody decisions, the wishes of natural parents often are given considerable weight. ${ }^{188}$ Contracts between spouses concerning custody of their children, however, generally are not binding on courts, although courts may give such contracts effect if they are consistent with the best interests of the child. ${ }^{189}$ The claims of a biological, noncustodial parent may weigh less heavily, however, when the biological mother is married to the man seeking parental rights despite the fact that he is not the adoptive father or the biological father, because courts prefer to uphold the marital union. ${ }^{190}$

188 See Alan Stephens, Annotation, Parental Rights of Man Who Is Not Biological or Adoptive Father of Child but Was Husband or Cohabitant of Mother When Child Was Conceived or Born, 84 A.L.R. 4TH 655, 659-62 (1991 \& Supp. 1998) (summarizing the case law regarding the parental rights of nonbiological fathers).

189 See Atwood, supra note 179, at $143 \mathrm{n} .77$ (noting that both at common law and under the Uniform Premarital Agreement Act, courts decline per se enforcement of custody and support contracts, preferring, in general, a "best interests of the child" analysis). In the IVF context, however, a best interests analysis may be inappropriate because there is no child, or constitutional "person." An exception for contract terms in support of children is notable under a uniform regime which exhibits a strong preference for contract. See Annotation, Court's Power to Modify Child Custody Order As Affected by Agreement Which Was Incorporated in Divorce Decree, 73 A.L.R. 2D 1444, 1444 n.3 (1960) (stating the general rule that interspouse contracts regarding the custody of their children are not binding on courts). "The most commonly appearing kinds of rationale are that the welfare of the child transcends any agreement of the parties, and that custody agreements are not in the nature of property settlements." Id. at 1447 (Supp. 1997); see also Doyle v. McLoughlin, 536 N.Y.S.2d 918, 920 (App. Div. 1989) (recognizing that a custody agreement is not controlling on a court).

${ }^{190}$ See Michael H. v. Gerald D., 491 U.S. 110, 129-32 (1989) (upholding a law which denied a putative natural father the right to challenge the paternity of a natural mother's husband); John M. v. Paula T., 571 A.2d 1380, 1384-88 (Pa. 1990) (holding that a trial court could deny a motion to compel a husband to submit to blood tests because the husband's privacy interests and society's interest in protecting families outweighed the putative father's 
As for the rights of an unwed biological father to receive notice, a hearing, and a veto of adoption proceedings involving his child, the Supreme Court has articulated a right of opportunity interest in parenthood. ${ }^{191}$ State courts have held, in the context of pre-birth and early infant adoptions, that expressing interest in the child, objecting to adoption of the child, and participating in the adoption proceedings may sufficiently manifest an unwed father's intent to seize his opportunity interest. ${ }^{192}$ Pre-birth commitment by a father often is considered in the context of the waiver of his parental right to object to an adoption. ${ }^{193}$

In the scheme of [Steven A. v. Rickie M. (In re Adoption of Kelsey S.), 823 P.2d 1216 (Cal. 1992)] and [In re Raquel Marie X., 559 N.E.2d 418 (N.Y. 1990)], once a man "fathers" a child, he acquires an "opportunity interest" in it that must be evaluated independently of his relationship with the mother or intent to form a family unit with her. ${ }^{19}$

The custody rules regarding children reveal the inconclusiveness of disposition determination. The fathers in both Davis and Kass asserted that if they lost the custody fight over the preembryos, they would seek custody of

interest in asserting his patemity); see also Monroe v. Monroe, 621 A.2d 898, 904-05 (Md. 1993) (holding that it was error to treat a husband as having subordinate rights to those of his ex-wife, the natural mother, and his ex-wife's lover, the natural father, where the nature and duration of his relationship with the child was such that he had clearly acted as a father and continued parental rights were in the best interests of the child); Ettore I. v. Angela D., 513 N.Y.S.2d 733, 739 (App. Div. 1987) (holding that a natural father was estopped from asserting paternity where a natural mother's husband had become the "psychological parent" of the child (citation and internal quotations omitted)).

191 See supra notes 106-08 (citing case law about the rights of unwed biological fathers to veto the adoption of their children); infra note 193 (same).

${ }^{192}$ See, e.g., In re Adoption of B.G.S., 556 So. 2d 545, 556 (La. 1990) (holding that an unwed father made sufficient efforts to demonstrate his devotion to his child); In re Baby Girl S., 559 N.E.2d 418, 424 (N.Y. 1990) (finding that a personal and legal action by an unwed putative father was sufficient to activate his liberty interest in his relationship with his putative child). Commitment to the child's mother may not be a necessary expression of parental interest. See, e.g., Doe v. Chambers, 374 S.E.2d 758, 759-60 (Ga. Ct. App. 1988) (finding a father's efforts to establish a parental relationship sufficient although he did not know the child's mother was pregnant and did not know about the child until two months after the child's birth).

${ }_{193}$ See Barbara Bennett Woodhouse, supra note 103, at 1797, 1797-98 \& nn.222-24 (citing Doe v. Roe (In re Adoption of Doe), 543 So. 2d 741, 747 (Fla. 1989), and holding that a father who favored abortion, who failed to provide emotional or material support during gestation, and who would not commit to marriage had waived his right to block adoption as a result of "abandonment"). But see In re Adoption of Stunkard, 551 A.2d 253, 256 (Pa. Super. Ct. 1988) (holding that the statutory period for a father to perform parental duties did not toll during gestation).

${ }^{194}$ Woodhouse, supra note 103, at 1801-02. 
any resultant children. ${ }^{195}$ It would be difficult to contend that the fathers had behaved in a manner inconsistent with parenthood. Rather, they would have behaved in a manner inconsistent with parenthood only in the context of dissolving their marriages.

In the context of IVF disputes, the deferrence to the parties' contract is grounded in the belief that parties should be able to resolve their own intrafamily disputes. ${ }^{196}$ Repose, however, could be precluded by state custody laws. For example, the parties' IVF contract, which granted custody of the frozen embryos to one parent, would be honored out of respect for the privacy of the family. Ultimately, however, custody of any children would depend on state-created law regarding the rights and responsibilities of biological parents against one another and towards a child. Custody battles would likely ensue, with issues of great complexity, far exceeding those of the clearly adulterous mother in Michael H. v. Gerald $D .{ }^{197}$ or the unknown parents in Buzzanca v. Buzzanca. ${ }^{198}$

An additional problem in bargaining under a contract regime is the question of enforceability. ${ }^{199}$ That is, contracts are formed against the background of the extant law, and must account for those rules. For two gender-specific reasons, IVF dispositional contracts ought not be given effect in the absence of a contemporaneous agreement. First, because a woman retains the right to abort a pregnancy, ${ }^{200}$ any woman carrying the disputed embryo would have the ability to frustrate the presumptive ration-

195 Junior Davis was explicit: "He testified quite clearly that if these preembryos were brought to term he would fight for custody of his child or children." Davis v. Davis, 842 S.W.2d 588, 604 (Tenn. 1992). Steven Kass was less explicit, although no less adamant. "I don't want to have children raised with Maureen. It is going to create a very strained, dysfunctional family situation,' Kass said. ..." Blaine Harden, N.Y. High Court to Decide Fate of Embryos that Survived Split, WASH. POST, Apr. 1, 1998, at A2. "I don't want my kids being brought up by her,' Steven [Kass] says." Adam Cohen, Test Tube Tug-of-War, TiME, Apr. 6, 1998, at 65, 65 .

196 See Kass v. Kass, 696 N.E.2d 174, 180 (N.Y. 1998) (holding that contracts between gamete donors which specify the disposition of their pre-zygotes are presumed to be binding).

197491 U.S. 110, 113-15 (1989) (concerning a challenge by a biological father to a Califormia paternity law and against a biological mother and her husband with respect to a child with whom the husband had established a relationship).

198 Buzzanca v. Buzzanca (In re Marriage of Buzzanca), 72 Cal. Rptr. 2d 286 (Ct. App. 1998) (involving two biological parents, two gestational parents, and two would-be legal parents).

See Marston, supra note 179, at 910 ("[L]egal rules affecting the parties' relative negotiating power influence the outcome of the negotiations."); see also Robert H. Mnookin \& Lewis Komhauser, Bargaining in the Shadow of the Law: The Case of Divorce, 88 YALE L.J. 950, 978-79 (1979) (discussing the effects of different judicial legal standards on the relative bargaining power of the parties).

${ }^{200}$ See supra Part II.B.1 (discussing the jurisprudence in the right to privacy area, including one's rights to marriage, divorce, procreation, and abortion). 
ale for the award in the first place-preference for life. Second, if a woman carries a pregnancy to term, she may have the power to preclude a father's assertion of rights in the adoption context, simply by not informing the agency or state of the natural father's identity. ${ }^{201}$ With respect to custody disputes over nonmarital children, it is the rule that a biological mother is the natural guardian of the child with rights and duties greater than those of the biological father. ${ }^{202}$ Where the biological mother does not reveal the identity of the natural father, an adoption will not be void on a subsequent challenge by the natural father. ${ }^{203}$

The reluctance to bind parties to contracts that were formed prior to marital dissolution and that concern children is due to the State's interests in the welfare of its citizens. ${ }^{204}$ Similar concerns have led to strict scrutiny of spousal support agreements. ${ }^{205}$ The general principle animating this scrutiny is that where a contract affects only the parties to the contract, it need not be scrutinized so carefully; however, where the agreement of the parties impacts third parties or society generally, there is a stronger state interest in the substance of the agreement. ${ }^{206}$

201 See Woodhouse, supra note 103, at 1797 n.221 (noting that states are divided with respect to the rights of unwed fathers to notice of adoption and termination of parental rights).

202 See Thomas J. Goger, Annotation, Right of Putative Father to Custody of Illegitimate Child, 45 A.L.R. 3D 216, 220, 223-24 (1972 \& Supp. 1998) (explaining that courts have generally held a biological father's rights to come before all other's rights, except for those of the natural mother).

${ }^{203}$ See In re Adoption of S.J.B., 745 S.W.2d 606, 609 (Ark. 1988) (holding that there was no constitutional violation where, due to concerns about religion and privacy, a mother did not reveal the name of the father who did not know of his child's birth and thus had not formed a relationship with the child); In re Karen A.B., 513 A.2d 770, 772 (Del. 1986) (holding that an unwed father's parental rights were terminable without notice where the child had been in foster care for one year and where the mother's privacy interests justified not disclosing the father). It is interesting that the State may severely limit an individual's right of procreation where a third party is affected. Further, it is noteworthy that such deprivations would be almost impossible within a marriage. An unwed father only gains limited procreative rights, subject to his acting like a wed father.

204 See Atwood, supra note 179, at 139-40 (noting that by utilizing the rationale of citizens' welfare, "courts have reasoned that agreements affecting property rights should be evaluated as of the time of execution whereas agreements affecting support rights should be assessed as of the time of the divorce").

${ }^{205}$ See id. at 136, 139-40 (discussing the variety of standards used by different courts to scrutinize such agreements).

${ }^{206}$ See id. at 132, 139-40 (noting the State's interest in stable marriages and the welfare of its citizens); see also Marston, supra note 179, at $898 \& \mathrm{n} .90$ (explaining that "[t]he most common types of provisions that courts have held invalid contravening public policy concern children, including waiver of child support, custody, or visitation rights"). In addition, courts generally do not enforce contractual provisions governing the conduct of an intact marriage. See id. at 900 (noting that courts adhere to the "well-established rule that it is improper for courts to interfere in a married couple's daily domestic affairs" (citation and internal quotations omitted)). 
In sum, the impact of the contracts on third parties, especially children, and the nature of the parents' relationship often stand as obstacles to strict enforcement of such contracts. ${ }^{207}$

\section{Revocability of IVF Agreements}

In light of the family rights and responsibilities explained in this Comment, a reasonable interpretation of the nature of the IVF endeavor, one which minimizes such disputes, should be sought. Simplistic IVF contracts generally ignore the divisible nature of the process. That is, donations of sperm and eggs create later options to exercise contracts concerned with implantation. Each implantation is thus a separate event, permitting and requiring mutual consent. ${ }^{208}$ It is not only that the IVF forum provides for the consent of both parties prior to each implantation; it requires it. ${ }^{209}$

For example, marriage is commonly acknowledged to be a contractual relationship, though the nature of the contract is disputed. ${ }^{210}$ Yet, in recent years marriage has become terminable at the will of either party. ${ }^{211}$ What once was understood as an irrevocable commitment is no longer considered as such. This shift is due to the fact that a bad marriage benefits no one.

207 A recent case in California illustrates the complex tangle of relationships which may arise as a result of IVF. The case involved two unrelated biological parents (donors), two gestational parents (surrogate and her husband), and two parents by "intent." After three years of litigation, the first three of the child's life, matters seem to have come to a rest. See Buzzanca v. Buzzanca (In re Marriage of Buzzanca), 72 Cal. Rptr. 2d 280, 293 (Ct. App. 1998) (holding that the parents by "intent" were the parents by law); see also Annas, supra note 8, at 935 (discussing the conclusion of the Buzzanca court that the parents by the intent were the legal parents because it was their contract which caused the child to be created).

Although the case, by the time of litigation, involved an extant pregnancy and is thus not applicable directly to the IVF context, it illustrates potential conflicts which are likely to arise after a disputed disposition. Science has made the lawyer's hypothetical real.

${ }^{208}$ Cf. Dehmel, supra note 4, at 1400 ("Cryopreservation... [adds] further steps of freezing and thawing the preembryos. As a result, there is room, and moreover a responsibility to accommodate the effect of shifting circumstances upon the parties' consent.").

209 Compare the IVF scenario where a couple undergoes treatment to that where a woman or man obtains sperm or eggs, respectively, from a donor's bank. In the latter case, it is not suggested that consent of the donor is necessary. The act of donating "at large" evidences no intent to be a parent. It is not only a waiver against one party, but a waiver against all the world of one's interest in avoiding biological parenthood. The IVF context is more analogous to the consensual procreative behavior of couples in their bedrooms. No longer does a spouse have "access" by the mere fact of consent to marriage.

210 See, e.g., Reynolds v. United States, 98 U.S. 145, 165 (1878) (characterizing marriage as a sacred obligation and a civil contract); Moskowitz, supra note 184, at A25 (noting that although marriage is legal status, it is not treated as a private contract entitling one spouse to legal or equitable relief).

211 See HARRIS ET AL., supra note 65, at 293-306 (discussing the advent and prevalence of "no-fault" divorce). 
Similarly, where childbirth will predictably entail dispute and hardship, and where a person in a constitutional and biological sense has not developed, the IVF contract need not be treated as binding or deserving of specific performance.

\section{Inability to Achieve the Aims of Privacy and Autonomy}

Leaving the parties to the language of IVF contracts will necessarily involve courts in the most intimate decisions a couple can make. Worse, it will not clarify the rights and expectations of the parties. Witness, for example, the dispute among the five Kass judges in the intermediate appellate court as to whether the language in the agreement revealed an unambiguous intent. Despite the existence of a contract, legal proceedings and analysis often will ensue.

Moreover, there will be inevitable lapses of contract. For example, the facility to which Mary Sue and Junior Davis went did have an informed consent document which the facility provided as a matter of policy. Due to the facility's move to a different location, howeyer, the documents were unavailable at the time the Davises began treatment. ${ }^{212}$

\section{E. Material Term of the Contract Was Marriage}

Couples who enroll in IVF clinics as couples usually envision parenthood and children only within marriage. ${ }^{213}$ Individuals, as couples, will only enroll in the hopes that they will be able to become parents together. ${ }^{214}$ Moreover, clinic selection procedures may emphasize the centrality of marriage to the decision to have children, such that participants are there only because they want children within the context of marriage. ${ }^{215}$ When couples

212 See Davis v. Davis, 842 S.W.2d 588, 592 n.9 (Tenn. 1992) ("Apparently the clinic was in the process of moving its location when the Davises underwent this last round and... it was impossible to postpone the procedure until the appropriate forms were located."); Poole, supra note 25, at 91 ("[T] here will always be situations in which the parties did not contract and for which a default rule is needed.").

213 "Instead of the ultimate goal being mere pregnancy, the parties might only have intended to have a child as a couple." Dehmel, supra note 21, at 1400; see also Ryan, supra note 27, at 1945 (noting that infertility is often met with intense "determination of infertile couples to have a child of their own by almost any means possible").

${ }^{214}$ See Kass v. Kass, 696 N.E.2d 174, 181 (N.Y. 1998) (taking the continued use of "we" in the contract as evidence that "they above all did not want. . . a stranger taking that decision our of their hands," and giving no serious weight to the contention that the contract was only intended to be for the benefit of the clinic or that it manifested the cognitive dissonance and psychological resistance which may characterize such agreements).

${ }^{215}$ See Steinberg, supra note 64, at 36-39 (criticizing the practice of British IVF clinics to select couples based on a perceived commitment to children within marriage). 
divorce and are no longer able to become parents together, the terms of their agreement have been frustrated and should not be specifically enforced. ${ }^{216}$

\section{THE RIGHT TO BEAR OR BEGET: VETO OF IVF IMPLANTATION}

Having said much, a brief recap may be in order. First, IVF makes it possible for many couples to bear genetically-related children. It also, however, confronts divorcing couples with the question of who should be able to control disposition of unused frozen embryos. Second, the dynamic nature of these embryos must be borne in mind and, although they are early in the continuum of life, they are entitled to special respect. Third, the constitutional right to procreation is derived from the right to family. Consequently, the State may extend greater procreational freedom to those who have assumed the obligations and responsibilities of marriage than it must grant to those who have made no such promises. Fourth, contracts are an inappropriate, inadequate means of protecting the privacy of families and often may have the anomalous results of making private interests public. Moreover, contractual resolution may be undermined by laws regarding child custody-laws directly implicated precisely because the embryo is dynamic. The embryo has the potential to become a constitutional person, and in so doing, to render one adjudication meaningless in the face of a later one.

Consequently, another rubric is needed to provide guidance to couples who avail themselves of IVF procedures. Professor Carl Schneider suggests that current responses to difficult moral and ethical questions are resolved frequently in one of two fashions: deference to ad hoc committee decisionmaking (whether the committee is composed of parents or professionals), ${ }^{217}$ or rights-based solutions. ${ }^{218}$ Parts II and IV of this Comment attempt to define the interests at issue and illustrate the ineffectiveness of case-by-case resolution in protecting these or other social interests. Rather, I suggest a rights-based approach. It is helpful to consider such solutions in light of

216 See, e.g., RESTATEMENT (SECOND) OF CONTRACTS $\$ 261$ (1981) (explaining that a duty of performance is discharged upon the "occurrence of an event the non-occurrence of which was a basic assumption orwhich the contract was made"). It is helpful to recall the suggestion from Part IV.A that people do not expect to divorce, even though they know they may. See also id. $\$ 265$ (discharging a duty of performance where the principal purpose of the party has been "substantially frustrated ... by the occurrence of an event the non-occurrence of which was a basic assumption on which the contract was made").

217 See Carl E. Schneider, Rights Discourse and Neonatal Euthanasia, 76 CAL. L. REV. 151,154 (1988) (discussing whether hospital committees should decide if neonatal euthanasia is appropriate or whether it should be a parent's right to decide).

218 See id. at 153-54 (suggesting that rights discourse may preclude a more valuable social discussion of seemingly intractable disputes involving a confluence of legal, ethical, and emotional concerns). 
Professor Scheider's three principal objections to intra-family rights-based arguments. First, he notes that rights discourse is derived from the "Mill paradigm," which conceives of rights as those of the individual against the power of the State. ${ }^{219}$ The obvious problem, he suggests, is that family disputes generally pit one member against another, and neither against the State. ${ }^{20}$ Second, he argues that there is no cohesive theory of the origin or incidents of the rights of family, thus giving little guidance for weighing the rights of parents and children. ${ }^{221}$ Finally, he discusses the social and psychological consequences of rights discourse-encouraging the more selfinterested impulses of the individual as opposed to the imposition of a burden on the individual for social reasons. ${ }^{222}$ Ultimately, he argues, the lack of any clear limits on "privacy" rights approaches will encourage a fear of slippery slopes, distorting the argument and polarizing society. ${ }^{22}$

In light of Schneider's concerns, and in light of the social limits on individual rights and the constitutional origins of the right of procreation, this Part reviews several other suggested approaches to embryo disposition disputes. Finally, a bright-line rule is proposed.

\section{A. Interest Balancing}

In Davis, the court weighed the relative interests of the specific parties in their rights of procreation and non-procreation. ${ }^{224}$ The Davis court established a presumption in favor of the party opposed to implantation, subject to consideration of the interests of the party who favored implantation when implantation was that party's last reasonable opportunity to achieve parent-

219 See id. at 157 (describing the failure of the "Mill paradigm" in family law situations).

220 See id. at 157-58 (noting that because both parties are individuals, an individual versus individual scenario makes ineffective our general presumption that the individual's rights are given more weight than society's).

221 See id. at 158-59 (noting that in many legal controversies, there is a theory to guide the court in making their decision, usually a political theory, which is absent in the parental rights question).

${ }^{222}$ See id. at 161-63 (discussing failures, such as Prohibition, of the law's attempt to encourage people to make certain moralistic decisions). In this respect, Schneider echoes a familiar theme: legal rights are conceived of as those of the individual and tend to encourage meaner, self-concerned behavior, in contrast with moral rights, which recognize obligations and encourage relationships.

${ }^{223}$ See id. at 166-73 (describing the various insufficiencies of both the liberal and conservative views of rights in the neonatal euthanasia debate and discussing how both sides employ the use of warnings about the slippery slope dangers of the other side in defense of their own position).

${ }^{224}$ See Davis v. Davis, 842 S.W.2d 588, 604 (Tenn. 1992) ("If no prior agreement [regarding the fate of the frozen embryos] exists, then the relative interests of the parties in using or not using the preembryos must be weighed."). 
hood. ${ }^{225}$ The Davis court thought its interest balancing was supported by Supreme Court precedent regarding the right to procreate and an equivalent right not to procreate. ${ }^{226}$

This interest-balancing analysis ignores several issues. First, the balancing analysis converts the inquiry into what the contract analysis sought to avoid in the first place-an intrusion on the sacred space of individual decision-making and private ordering. ${ }^{227}$ Finding that the decisions involved concerned intimate and private matters, the court ironically adopted a default rule certain to increase, rather than decrease, the level of intrusion into that private sphere. ${ }^{228}$

Second, the Davis court's opinion presumed that the rights to procreate and not to procreate were of equal weight for an unwed couple. This presumption is questionable. The rights at issue are anchored in marriage and private consent. ${ }^{229}$ When such rights have been extended beyond the marital relationship, they have only reached situations where their exercise was sought to limit the socially injurious consequences of sexual relationships: access to contraception and abortion. ${ }^{230}$

Considered against the criteria set forth at the beginning of this Part, these failings are fatal. First, a balancing analysis does not preclude the potentially unclear and public custody litigation that would follow implan-

225 See id. "If no other reasonable alternatives exist, then the argument in favor of using the preembryos to achieve pregnancy should be considered.").

${ }^{226}$ See id. at 598-603 (examining the history of the right to privacy and procreation by reviewing Supreme Court cases including Meyer v. Nebraska, 262 U.S. 390 (1923); Griswold v. Connecticut, 381 U.S. 479 (1965); Skinner v. Oklahoma, 316 U.S. 535 (1942); and Roe v. Wade, 410 U.S. 113 (1973)); cf. supra Part II.B (discussing the constitutional rights to privacy, including marriage, procreation, and abortion).

${ }^{227}$ See Davis, 842 S.W.2d at 603 (arguing that the dramatic impact of parenthood on the individuals who comprise a couple "supports their right to sole decisional authority as to whether the process of attempting to gestate these preembryos should continue"); see also Planned Parenthood v. Casey, 505 U.S. 833, 857 (1992) (recognizing "liberty relating to intimate relationships, the family, and decisions whether or not to beget or bear a child"); Kass v. Kass, 663 N.Y.S.2d 581, 590 (App. Div. 1997) (finding the informed consent document evidence of the parties' intent involving "intensely personal and essentially private matters which are appropriately resolved by the prospective parents rather than the courts"), affd, 696 N.E.2d 174 (N.Y. 1998).

228 See Davis, 842 S.W.2d at 604 (holding that an interest-balancing approach should be used as a default rule when no prior agreement exists as to the disposition of the preembryos).

229 See supra Part II.B (explaining that the rights of procreational privacy originated in cases stressing the importance of protecting the procreative marital relationship from governmental interference).

230 See supra Part II.B (analyzing cases that discuss the rights to procreation and abortion in terms of the burdens that unwanted pregnancies place on both married and unmarried persons). 
tation. $^{231}$ Second, an interest-balancing analysis vests in an individual, who expressly disavows a social contract, a right derived therefrom. ${ }^{232}$ In so doing, a balancing analysis severs the line holding the right to procreation to the constitutional anchor of the right to privacy within the marital relationship. Third, a balancing analysis explicitly pits one family member against another, creating an awkward clash of rights that are normally understood to exist only against the State. ${ }^{233}$ Fourth, a balancing analysis encourages vitriolic custody fights, two such cases having been taken to state high courts. ${ }^{234}$ The interest-balancing analysis uses a questionable means to achieve uncertain ends. A better way is sought.

\section{B. The Sweat Equity Model}

Under the Sweat Equity model for rights allocation, the party who has invested the most in the procedure should be given discretion over the disposition of the embryos. ${ }^{235}$

This model is inappropriate on pragmatic grounds. First, the physical investment argument would seem to justify a woman's absolute control over all reproductive decisions, because she will seem to invest more in the process. $^{236}$ She will not always invest more, however. Recall that IVF may be necessary due to male factor infertility. ${ }^{237}$ It is noteworthy that a man "can now share with his partner the various invasive medical technologies" such as intracytoplasmic sperm injection (ICSI), which involves biopsy of a testicle and aspiration of sperm. ${ }^{238}$ Even where male factor infertility is not a central issue, "[s]emen collection may be especially difficult because the

231 See supra Part IV.B (arguing that legal rights involved in IVF disputes can be unclear due to the weight given to the third party and social interests considered in subsequent child custody disputes).

${ }^{232}$ See supra Part II.B (explaining that procreational privacy was found archetypally in the marital relationship).

233 See supra note 227 and accompanying text (referring to the difficulty of weighing the rights of individuals against those of other individuals when the rights at issue were created specifically against the government).

${ }^{234}$ See supra Parts III.A-B (discussing Davis v. Davis, 842 S.W.2d 588 (Tenn. 1992) and Kass y. Kass, 696 N.E.2d 174 (N.Y. 1998)).

235 See John A. Robertson, Resolving Disputes over Frozen Embryos, HASTINGS CTR. REP., Nov./Dec. 1989, at 7, 7-8 (describing and critiquing the Sweat Equity model).

236 See supra notes 12-15 and accompanying text (describing the process of in vitro fertilization and the demands placed upon the woman's body, including ovarian hyperstimulation, aspiration of the eggs, and insemination).

${ }^{237}$ See Davis \& Rosenwaks, supra note 8, at 2320-22 (discussing the causes of infertility).

238 Olivennes \& Frydman, supra note 12, at 1121 (criticizing the prevalence of invasive and burdensome IVF techniques). 
emotional pressure to perform and to provide a good-quality specimen is particularly powerful.,239 The Sweat Equity inquiry is unclear and intrusive, requireing detailed physical and emotional analysis in open court. Prior to implantation, the parties stand on uniquely equal ground. To tilt the surface may cast all couples down a slippery slope.

Second, the Sweat Equity model introduces a new inquiry which never before has been applied in the area of reproductive, as opposed to custodial, privacy - the degree to which a specific person is personally invested in the procreative event. ${ }^{240}$ Further, the Sweat Equity model is inconsistent with many state custody and adoption statutes which focus on the welfare and well-being of a child, not solely on the parental investment in the child. ${ }^{241}$ Where a third person will be impacted by the exercise of individual discretion, courts have inquired as to the consequences of a course of action, not the parties' personal investment in the action itself. ${ }^{242}$ The embryo is not, of course, a constitutional "person." 243 The point, however, is that the embryo

239 Applegarth, supra note 46, at 1960.

240 In Skinner v. Oklahoma, 316 U.S. 535 (1942), the Court considered the general impact of compulsory loss of the reproduction function. See supra notes 55-61 and accompanying text (describing the application of strict scrutiny to a law requiring the forced sterilization of some felons). In Griswold v. Connecticut, 381 U.S. 479 (1965), the Court deferred to the general privacy of a married couple despite the fact that their reception of contraceptives was at a public discussion. See supra notes 66-71 and accompanying text (analyzing the grounds for the privacy right found in Griswold). In Eisenstandt v. Baird, 405 U.S. 438 (1972), a single person presented a successful facial challenge to a law prohibiting the sale of contraceptives to, or use of contraceptive by, single persons. See supra notes $72-75$ and accompanying text (describing the extension of the privacy right found in Griswold to unmarried persons). In Roe v. Wade, 410 U.S. 113 (1973), an abortion prohibition was facially unconstitutional because of the harms of unwanted pregnancy and parenthood generally, but the law was not analyzed as it applied to individuals. See supra notes 79-91 and accompanying text (describing the extension of the privacy right to the decision of a woman to terminate a pregnancy). And in Michael H. v. Gerald D., 491 U.S. 110 (1989), the Court declined to confer a right of parenthood on an adulterous father despite his relationship with his biological child, deferring to the general principle favoring marriage. See supra note 106 (upholding a law that privileged the rights of a husband over those of a man claiming to be the biological father of a child). In all these cases and more, the inquiry has been general and not specific.

${ }^{241}$ See supra Parts IV.A-B (describing the various factors given weight in adoption and custody decisions).

242 See Roe, 410 U.S. at $153-54$ (balancing the infringement of a woman's privacy right if abortion is forbidden against the harm to the State's interests in regulating health and medicine and protecting potential life if abortion is allowed); see also Davis v. Davis, 842 S.W.2d 588,598 (Tenn. 1992) (characterizing the central inquiry as "whether the parties will become parents"); supra Part IV.B (emphasizing state law's reluctance to enforce, per se, contracts that are made in advance and that are related to adoption or custody of children).

${ }^{243}$ See supra Part II.A (arguing that the "special respect" view of the preembryo is the best characterization). 
may come to be a "person" in the future, and, moreover, the disposition of the embryo will not conclusively settle all custody disputes. ${ }^{244}$

Third, granting custody based on investment ensures nothing. As shown earlier, a woman may abort a pregnancy free of any veto power by her partner. ${ }^{245}$ Consequently, she may thwart a disposition favoring implantation-even for spite.

Analyzed against Professor Schneider's criteria set out at the beginning of this Part, the Sweat Equity Model is also inadequate. First, it gives an individual a right derived from the family and necessarily draws the public into the private realm as an arbiter. ${ }^{246}$ Second, it attempts to evaluate the rights of a married couple to procreate as against other individuals where those rights have previously existed against the State only. ${ }^{247}$ Third, it does not ensure wise results, as a spiteful ex-spouse could seek custody only to abort. Nor would it prevent custody battles over any resultant children. The meaner impulses would be encouraged and the parties would wield their legal rights to the detriment of possible moral duties.

\section{An Automatic Right to Implantation}

Another argument advanced by some commentators favors the automatic right to implantation. ${ }^{248}$ This right, however, is illusory. First, it has no basis in the Constitution. Recall that there is no case which stands for the right of one person to compel procreational assistance from another. ${ }^{249}$ Second, the right is an illusion even if enforced because the person who implants the preembryo will always be a woman who will have an automatic veto over the pregnancy as part of her right to an abortion. ${ }^{250}$ Moreover, because unwed, biological fathers have a fleeting right to develop a relation-

244 See supra Part IV.B (describing the obstacles that state custody laws place in the way of settling the custody issues prior to birth).

${ }^{245}$ See supra Parts II.B, IV.B (noting that a woman's right to terminate her pregnancy cannot be stopped by her husband or the biological father of her child).

${ }^{246}$ See supra Part II.B (arguing that the courts base procreational privacy rights on the marital relationship).

${ }^{247}$ See supra Part II.B (describing the origin of the privacy right in the marriage relationship).

The American Bar Association recently shelved a proposal which would have favored the spouse seeking to implant the preembryos. See No ABA Embryo Policy, WASH. POST, Feb. 3, 1998, at A5 (describing the informal vote at the ABA annual meeting and the general contours of the policy); see also Panitch, supra note 8, at 545 (favoring implantation where the spouse seeking custody accepts sole responsibility for the child's care).

249 See supra Part II.B (explaining the limited nature of the right to procreate).

250 See supra Parts IV.B-C (explaining the right to abortion and the impact it could have on a contract analysis). 
ship with their genetic offspring, ${ }^{251}$ implantation may drive the noncustodial spouse to intervene in a custody battle to preserve parental rights. In this respect, it is noteworthy that men's attitudes towards child rearing are changing, strengthening the argument that men may be affected by the knowledge that they have children whom they do not know or raise. ${ }^{252}$ Consequently, implantation will not resolve any child custody disputes but is only a temporary fix to a larger problem. ${ }^{253}$ Third, this right does not address the concern of the spouse opposing implantation: he or she does not want the irrevocability of parenthood outside of marriage. The "decision to have or to forego having a child is one of the most crucial and, at a certain point, uniquely irrevocably [sic] decisions that individuals face.,254 In this respect, it is important to recall the psychological significance of genetic reproduction to most people. ${ }^{255}$ Biology has always received strong consideration in the law: "The traditional rule, both in custody and visitation disputes, is that a [biological] parent prevails against a non-parent, unless shown to be unfit or to have abandoned his or her rights."256 Consequently, parents who have undergone IVF may be unwilling to accept the fact that they have biological offspring for whom they do not function as parents in a nurturing sense.

251 See supra note 106 and accompanying text (describing several cases dealing with the rights of unwed fathers in adoption proceedings).

252 See Stephanie B. Goldberg, Make Room for Daddy, A.B.A. J., Feb. 1997, at 48, 48-52 (discussing the "Father's Rights Movement," comprised of "various factions" which share the belief "in the importance of father involvement in families" and are working to effectuate it); Karen Secombe, Assessing the Costs and Benefits of Children: Gender Comparisons Among Childfree Husbands and Wives, 53 J. MARRIAGE \& FAM. 191, 200 (1991) (finding that "men rate the importance of having children higher than women do, and they are also more apt to want to become parents themselves"); supra note 193 (explaining the testimony of a spouse that if embryos were brought to term, custody of the child would be sought). "[W] hile men and women do not differ in the importance placed upon benefits and/or costs [of] ... parenthood, different factors do indeed emerge as significant determinants of their perceptions. For too long, data on men have been ignored because of the presumption that women are responsible for fertility decisions." Secombe, supra, at 201. The Supreme Court has recognized that assumed distinctions in the relationships between men and women and their children, drawn broadly along gender lines, are not constitutional. See Caban v. Mohammed, 441 U.S. 380, 394 (1979) (holding that a statutory definition of fitness to be a parent, which distinguished between men and women generally, was contrary to the Equal Protection Clause of the Fourteenth Amendment).

253 See supra Part IV.B (describing the potential for complex custody disputes should implantation proceed despite one parent's opposition).

254 Mary-Joan Gerson et al., The Wish for a Child in Couples Eager, Disinterested, and Conflicted About Having Children, 19 AM. J. FAM. THERAPY 334, 342 (1991).

255 See Applegarth, supra note 46, at 1960 (noting the unique importance to patients of a biological relationship with their child).

256 Woodhouse, supra note 103, at 1785 n.149 (quoting IRA M. ELLMAN ET AL., FAMILY LAW: CASES, TeXT, Problems 600 (2d ed. 1991)). 
It has been suggested that the focus of parental rights ought to be on the rights of children-a focus on nurturing. ${ }^{257}$ Extending this analysis, the parent most willing or able to nurture the child would be entitled to custody. Three responses are appropriate. First, there is no denying the strength of biological attachment, as noted above. Second, in an IVF context, conception is delayed. The parties' relationship could go bad before conception occurs. Realization of potential life at this point is statistically unlikely. ${ }^{258}$ The promise of life is too remote and too attenuated. Moreover, a gestational parent may always thwart the interest of the other nurturing parent by aborting the pregnancy. Finally, the failure of the marriage before the need for nurturing the child arises should inform our sensibilities as to the longterm consequences: if we reward only nurture, custody disputes would actually increase because parents would fight even harder from the outset of the dispute. Parents would know that, with the importance of biological ties legally limited, the opportunity interest in gaining custody would be even more pivotal than before.

\section{The Right to Procreate-The Right to No}

IVF is a new technology. It has made dreams come true for many, but the price of those dreams is uncertain. Specifically, the scientific data regarding the harms and long-term consequences of IVF are not clear at all. ${ }^{259}$ This is particularly frightening given the lack of regulation of IVF procedures. $^{260}$

Against the backdrop of this unregulated technology, courts and couples need a clear understanding of how to resolve disputes over the disposition of frozen embryos. The legal principles set forth in this Comment lead to the conclusion that implantation requires contemporaneous mutual consent for a

257 See, e.g., Woodhouse, supra note 103, at 1749 (advocating '“'generism' that would evaluate parents' authority over children and their obligations to children, and to each other, through the lens of children's needs and experiences").

${ }^{258}$ See Rutter, supra note 7 , at 68 (noting that a $25 \%$ pregnancy rate is probably high).

259 See Olivennes \& Frydman, supra note 12, at 1121 (discussing the potential dangers of IVF for women); E.R. te Velde et al., Concerns About Assisted Reproduction, 351 LANCET 1524,1525 (1998) (discussing the potential harm to children's genetic material by IVF and currently inadequate tests for genetic damage, concluding that techniques "should be assessed extensively," and analogizing the threat of genetic damage to that of "[1]essons learnt from the unexpected effects on fetal development of drugs that were not adequately assessed"); Templeton \& Morris, supra note 13, at 573 (characterizing the IVF risk of multiple births as a "major health issue").

${ }^{260}$ See Annas, supra note 7, at 938 (assessing the need for federal regulation of assisted reproduction); ISLAT Working Group, supra note 7, at 651 (noting that adoption is more heavily regulated than assisted reproduction and suggesting reforms). 
married couple and that their divorce will result in the destruction or donation of unused frozen embryos.

This rule recognizes the differences between married and unmarried persons. As interpreted, the right to procreate has its roots in the marital relation. ${ }^{261}$ Such a distinction is constitutional because married couples assume obligations as a matter of law which single persons do not. ${ }^{262}$ Moreover, sexual intercourse between certain populations remains illegal. ${ }^{263}$

There is also a constitutional right not to procreate. First found within marriage, this right was later extended to single persons in an effort to minimize the social consequences of consensual, albeit sometimes illegal, sex. $^{264}$ Most significantly, the right was extended to include a woman's ability to terminate a pregnancy rather than suffer a lifetime of irrevocable parenthood. ${ }^{265}$

Finally, state law favoring marriage over biology and seeking to minimize intrusion into private matters favors a restriction of the procreational rights of an individual when that right is, or may be, opposed by another individual whose procreational rights are implicated.

When analyzed against Professor Schneider's critique of rights-based solutions, this Comment's proposal fares well. First, the rule does not pit the right of one individual against the rights of another, but rather says that, as a constitutional matter, neither person individually possesses these rights. ${ }^{266}$ Thus, it is not as much of a legal quandary as a "Mill paradigm" might present. ${ }^{267}$ Consequently, the status quo is preserved at the sufferance of no rights. Second, the rule is drawn from a cohesive, if controversial, understanding of the privacy right to procreation: it is granted to those married in exchange for their assumption of the responsibilities of mar-

${ }^{261}$ See supra Part II.B.1 (describing the Court's treatment of marriage and procreation as protected rights).

262 See supra note 108 and accompanying text (noting that married fathers have been given greater rights than unmarried fathers on the grounds that they have incurred greater obligations).

${ }^{263}$ See GA. CODE ANN. § 16-6-18 (1996) (criminalizing fornication, which is intercourse between unmarried individuals); IDAHO CODE § 18-6603 (1997) (same); MASS. GEN. LAWS ch. $272 \S 18$ (1998) (same).

264 See supra Part II.B (discussing the limited extension to unmarried persons of a privacy right grounded in marriage).

${ }^{265}$ See supra notes $89-93$ and accompanying text (describing the Roe Court's view of an unwanted pregnancy as a harm and a burden).

${ }^{266}$ See supra Part II.B (noting that the privacy right is based in the marriage relationship).

See supra notes $218-23$ and accompanying text (explaining that people usually think of rights as against the State only). 
riage. ${ }^{268}$ It does not suffer from the doctrinal atomization that is characteristic of pleas for individual rights. The rule derives from a limited, but faithful, understanding of Supreme Court cases. ${ }^{269}$ The rule is notable for its restriction, but not violent in its constitutional interpretation. Third, the rule prevents disposition disputes and, unlike a rule favoring implantation, it precludes custody battles over resulting children. Such a rule does not add a bargaining chip (that otherwise would not exist) to a divorce battle because it presupposes disagreement and does not condition its grant on the parties' bargain. Finally, the rule recognizes that children are social beings and that assisted reproduction "involves creating children and building families, a fundamental social value.,"270

Hearts are sure to break, yet this will occur no matter which course is chosen: the response is implicit in a dispute over such an intimate matter. Nonetheless, the decision to have a child is private only as between two persons and has infinite social consequences. Consenting married adults engaged in a course of married conduct, for which they assume responsibility in exchange for the grant of a right, are in a different position than those who have assumed no such obligations but seek the same opportunities. Their rights to procreation are not the same, and there is no need for a judicial construction to read them as the same.

\section{CONCLUSION}

This Comment evaluates the right to custody of frozen embryos produced by IVF. It demonstrates that currently, a preference for a contract analysis exists, such that courts profess a willingness to honor any agreement made by the parties at an earlier time. It also demonstrates that a contract analysis is inappropriate, inadequate, and anomalous.

268 See supra Part II.B.2 (describing the extension of greater rights over children to those who accept greater parental responsibilities over children).

269 See supra Part II.B (reading the language of procreative rights cases against the facts and circumstances from which they emanated).

270 ISLAT Working Group, supra note 7, at 652; see also Annas, supra note 7, at 937 ("[C]ertain aspects of these decisions have such a strong impact on matters of concern to society ... that they require public scrutiny and regulation." (citations omitted)) In this respect, the effect of a single-parent upbringing or of contentious parental relations on children are notably negative. See, e.g., MARK ABRAHAMSON, OUT OF WEDLOCK BIRTHS: THE UNITED STATES IN COMPARATIVE PERSPECTIVE 17 (1998) (explaining the significance of parent-child bonds for both parents); J. Owusu-Bempah, Information About the Absent Parent as a Factor in the Well-Being of Children of Single-Parent Families, 38 INT'L SOC. WORK 253, 266-70 (1995) (explaining hardships as being based on the quantity and quality of information about an absent person). 
This Comment also analyzes the right to procreate. Considering the source of that right, this Comment suggests that prior to pregnancy, the positive and negative facets of the right to procreation are limited to the marital relation, while its negative aspects are extended to single individuals as a socially justified limit on responsibility. This Comment suggests that a bright-line rule in the IVF context best comports with constitutional interpretation, policy considerations, and judicial objectives. Implantation by a married couple requires contemporaneous mutual consent and implantation by a divorcing couple who dispute the disposition is precluded. Simply, this Comment argues that the right to procreate, in the context of IVF, need not and should not go beyond the right to say no. 
